NBER WORKING PAPER SERIES

DEPOSIT INSURANCE DATABASE

Asli Demirgüç-Kunt

Edward J. Kane

Luc Laeven

Working Paper 20278

http://www.nber.org/papers/w20278

\author{
NATIONAL BUREAU OF ECONOMIC RESEARCH \\ 1050 Massachusetts Avenue \\ Cambridge, MA 02138 \\ July 2014
}

This research was performed at the IMF and World Bank. This paper was also published as IMF Working Paper 14/118. We would like to thank Belen Bazano and Lindsay Mollineaux for excellent research assistance, and IMF colleagues for their useful comments and help in checking the accuracy of the database. The views expressed herein are those of the authors and do not necessarily reflect the views of the IMF, the IMF Board, the World Bank, or the National Bureau of Economic Research.

At least one co-author has disclosed a financial relationship of potential relevance for this research. Further information is available online at http://www.nber.org/papers/w20278.ack

NBER working papers are circulated for discussion and comment purposes. They have not been peerreviewed or been subject to the review by the NBER Board of Directors that accompanies official NBER publications.

(C) 2014 by Asli Demirgüç-Kunt, Edward J. Kane, and Luc Laeven. All rights reserved. Short sections of text, not to exceed two paragraphs, may be quoted without explicit permission provided that full credit, including $(\mathcal{C}$ notice, is given to the source. 
Deposit Insurance Database

Asli Demirgüç-Kunt, Edward J. Kane, and Luc Laeven

NBER Working Paper No. 20278

July 2014

JEL No. G01,G21,G28

\begin{abstract}
$\underline{\text { ABSTRACT }}$
This paper provides a comprehensive, global database of deposit insurance arrangements as of 2013. We extend our earlier dataset by including recent adopters of deposit insurance and information on the use of government guarantees on banks' assets and liabilities, including during the recent global financial crisis. We also create a Safety Net Index capturing the generosity of the deposit insurance scheme and government guarantees on banks' balance sheets. The data show that deposit insurance has become more widespread and more extensive in coverage since the global financial crisis, which also triggered a temporary increase in the government protection of non-deposit liabilities and bank assets. In most cases, these guarantees have since been formally removed but coverage of deposit insurance remains above pre-crisis levels, raising concerns about implicit coverage and moral hazard going forward.
\end{abstract}

$\begin{array}{ll}\text { Asli Demirgüç-Kunt } & \text { Luc Laeven } \\ \text { The World Bank } & \begin{array}{l}\text { Deputy Division Chief } \\ \text { International Monetary Fund }\end{array} \\ \begin{array}{l}\text { 1818 H Street } \\ \text { Washington, DC 20433 } \\ \text { ademirguckunt@worldbank.org }\end{array} & \begin{array}{l}\text { Washington, DC 20431 } \\ \text { and CEPR }\end{array} \\ \text { Edward J. Kane } & \text { Llaeven@imf.org } \\ \text { Boston College } & \\ \text { 2325 E Calle Los Altos } & \\ \text { Tucson, AZ 85718 } & \\ \text { and NBER } & \\ \text { edward.kane@bc.edu } & \end{array}$

An online appendix is available at: http://www.nber.org/data-appendix/w20278 


\title{
Deposit Insurance Database
}

\section{Prepared by Asli Demirgüç-Kunt, Edward Kane, and Luc Laeven ${ }^{1}$}

June 2014

Demirgüç-Kunt is Director of Research at the World Bank; Kane is Professor of Finance at Boston College and a Research Associate of the NBER: Leaven is Lead Economist in the Research Department of the International Monetary Fund and Research Fellow at CEPR in London

\begin{abstract}
This paper provides a comprehensive, global database of deposit insurance arrangements as of 2013. We extend our earlier dataset by including recent adopters of deposit insurance and information on the use of government guarantees on banks' assets and liabilities, including during the recent global financial crisis. We also create a Safety Net Index capturing the generosity of the deposit insurance scheme and government guarantees on banks' balance sheets. The data show that deposit insurance has become more widespread and more extensive in coverage since the global financial crisis, which also triggered a temporary increase in the government protection of non-deposit liabilities and bank assets. In most cases, these guarantees have since been formally removed but coverage of deposit insurance remains above pre-crisis levels, raising concerns about implicit coverage and moral hazard going forward.
\end{abstract}

JEL Classification Numbers: G20

Keywords: Deposit insurance; Financial institutions; Financial crises

Authors’ E-Mail Addresses: ademirguckunt@worldbank.org; edward.kane@bc.edu; llaeven@imf.org

\footnotetext{
${ }^{1}$ We would like to thank Belen Bazano and Lindsay Mollineaux for excellent research assistance, and IMF colleagues for their useful comments and help in checking the accuracy of the database. The views expressed here are our own and not those of the IMF or IMF Board.
} 
CONTENTS

PAGE

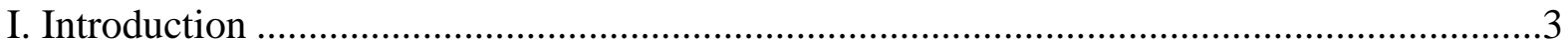

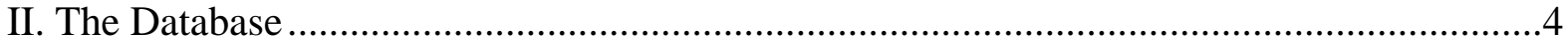

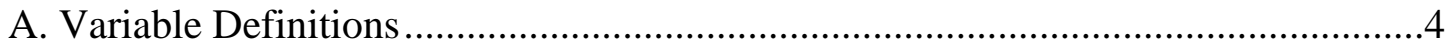

III. Main Features of Deposit Insurance Schemes Around the World..................................11

IV. Depositor Protection During the Global Financial Crisis............................................14

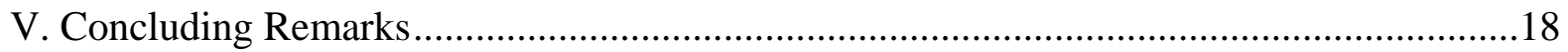

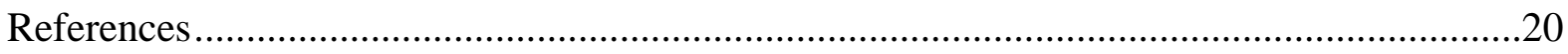

\section{Figures}

Figure 1. Explicit Deposit Insurance by Income Group, 2013 .........................................23

Figure 2. Explicit Deposit Insurance by Region, 2013 ...................................................23

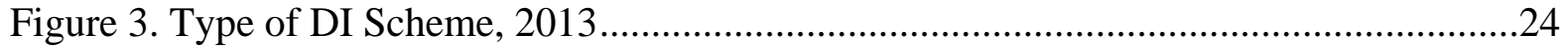

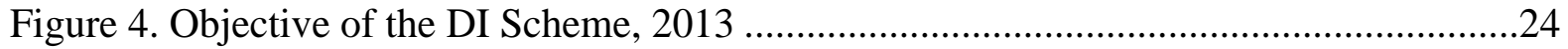

Figure 5. Organization of the DI Scheme, 2013 .............................................................25

Figure 6. Administration of the DI Scheme, 2013 .......................................................25

Figure 7. Funding of the DI Scheme, 2013.................................................................26

Figure 8. Coverage Increased During Crisis and Remains Above Pre-Crisis Levels..............26

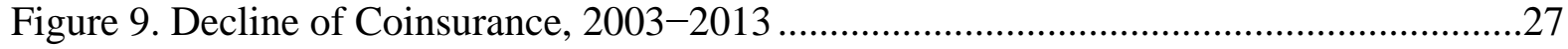

Figure 10. Risk Adjustment of DI Premiums, 2013 ...........................................................27

Figure 11. Government Support of DI Schemes, 2013.....................................................28

Figure 12. Increase in Depositor Protection, 2007-2013 …...............................................28

Figure 13. Potential Deposit Liabilities and Ability to Pay by the DIS Fund, end-2010 .......29

Figure 14. Total Deposits and Ability to Pay by the Government, end-2010 ......................29

Figure 15. Size of DIS Fund Relative to Covered Deposits and Government Indebtedness...30

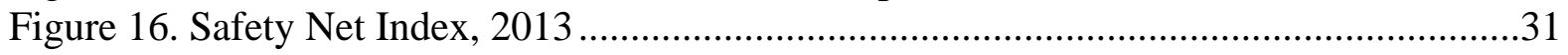

\section{Tables}

Table 1. Explicit Deposit Insurance Schemes Around the World, end-2013 ........................32

Table 2. Coverage of Explicit Deposit Insurance Schemes Around the World, end-2013 .....34

Table 3. Design of Explicit Deposit Insurance Schemes Around the World, end-2013 ..........37

Table 4. Recent Changes to Depositor Protection, 2007-2013 ............................................40

Table 5. Fund Size and Coverage of Existing DIS, 2010 ...................................................43 


\section{INTRODUCTION}

The recent global crisis tested and tried deposit insurance schemes (DIS), and their ability to protect household savings in banks. Country authorities and financial regulators reacted to the extraordinary circumstances of the crisis by expanding the coverage offered in existing deposit insurance arrangements or adopting deposit insurance where it was not already in place. This pattern of policy response exposed the adverse distributional effects of generous schemes and underscored the strengths and weaknesses of different DIS features.

This paper presents a comprehensive database of deposit insurance arrangements through the end of 2013, covering the IMF membership of 188 countries plus Liechtenstein. For countries with an explicit deposit insurance scheme, information is provided on the characteristics of the DIS (such as type, management, coverage, funding, and payouts). For recent years, we add information on deposit coverage increases, government guarantees on deposits and non-deposit liabilities, as well as whether a country experienced a significant nationalization of banks. To assess a country's ability to honor its deposit insurance (and other safety net) obligations, we supplement these data with information on the size of potential deposit liabilities, the amount of DIS funds, and government indebtedness.

While it is too early to draw definitive conclusions about the adequacy of DIS during the recent global financial crisis, our preliminary assessment is that, by and large, DIS fulfilled its foremost purpose of preventing open runs on bank deposits. In the face of large shocks to the global financial system, as well as concerted and protracted concerns about the solvency of practically every large financial institution in the world, we did not observe widespread bank runs. There were some notable exceptions (such as Northern Rock in the UK) and there were protracted withdrawals by uninsured depositors, but the world did not experience systemic bank runs by insured depositors. From this perspective, DIS delivered on its narrow objective. However, as we look to what we hope are many post-crisis years, the expansion of the financial safety net (both through an extended coverage of deposit insurance and increased reliance on government guarantees and demonstrated rescue propensities to support the financial sector) raises important research issues. These issues include: (i) whether government finances are adequate to support the promises of existing DIS in future periods of stress (the more so given that governments will likely face renewed pressures to further increase DIS promises in future crises) and (ii) how to balance the objective of preventing bank runs with the potentially negative effects of DIS in the form of moral hazard and the threat to financial stability from incentives for aggressive risktaking.

The rest of the paper is organized as follows. Section 2 describes the main database, with a description of each variable included. Section 3 surveys the current state of DIS worldwide. Section 4 reviews policies undertaken during the financial crisis period to protect depositors against the loss of value of their deposit savings. Section 5 concludes. 


\section{THE DAtABASE}

The database builds upon earlier work by Demirgüç-Kunt, Karacaovali, and Laeven (2005). The original dataset covered deposit insurance schemes through 2003. It was constructed through a combination of country sources, as well as earlier studies by Garcia (1999), Kyei (1995), and Talley and Mas (1990), among others.

This version updates the earlier database and extends it to 2013. Whenever possible, we relied on official sources. Our starting point was a comprehensive survey on financial sector regulations conducted by the World Bank in 2010. This survey asked national officials for information on capital requirements, ownership and governance, activity restrictions, bank supervision, as well as on the specifics of their deposit insurance arrangements. These data were combined with the deposit insurance surveys conducted by the International Association of Deposit Insurers in 2008, 2010, and 2011, and in the case of European countries with detailed information on deposit insurance arrangements obtained from the European Commission (2011). Discrepancies and data gaps were checked against national sources, including deposit insurance laws and regulations, and IMF staff reports. Information on government actions undertaken during the financial crisis was collected from Laeven and Valencia (2012), FSB (2010, 2012), Schich (2008, 2009), Schich and Kim (2011), and IMF staff reports.

Our focus is on deposit insurance for commercial banks. For countries with multiple DIS, the data provided relate only to the national statutory scheme. This means that stated coverage levels may understate actual coverage. For example, the complex voluntary DIS for commercial banks in Germany provides insurance of up to 30 percent of bank capital per depositor, essentially offering unlimited coverage for most depositors.

The full database, including information on arrangements other than the national statutory scheme, is available in spreadsheet format as an online Appendix to this paper. The source of the data is indicated in the appendix. The following section describes the variables used in the remainder of the paper.

\section{A. Variable Definitions}

\section{Type of deposit insurance}

We follow Demirgüç-Kunt, Kane, and Laeven (2006) in arguing that a country may be assumed to offer implicit deposit insurance, given the strength of governmental pressures to provide relief in the event of a widespread banking insolvency, unless the country has passed formal legislation or regulation outlining explicit deposit coverage. Indeed, implicit coverage always exists, regardless of the level of explicit coverage. Countries may have an explicit deposit insurance scheme without specifying an institution or fund to carry out powers laid out in statutes or regulation, but the issuance of temporary blanket guarantees by the government is not sufficient to qualify as having explicit deposit insurance. Hence, we assume that any country that lacks an 
explicit deposit insurance scheme has implicit deposit insurance. Explicit takes a value of one if the country has explicit deposit insurance, and zero if implicit. Table 1 lists all countries with explicit deposit insurance.

\section{Coverage}

Explicit deposit insurance schemes typically insure deposits up to a statutory coverage limit. Particularly during banking crises, countries often issue guarantees on top of pre-announced, statutory limits. We provide information on both the statutory limits, and the limits taking into account additional government guarantees. Coverage is the coverage limit in local currency. It takes on a numerical value or "unlimited" if a full guarantee is in place. Coverage / GDP per Capita is the ratio of the coverage limit to per capita GDP, expressed as a percentage, and based on the statutory coverage limit. Table 2 reports these coverage limits both in reported (typically local) currency and translated in US dollars (using end-of-year exchange rates). Data on GDP per capita is taken from the April 2014 IMF WEO database, unless otherwise noted. Footnotes accompanying Table 2 specify the coverage limits for individual countries. For countries with coinsurance, coinsurance rules are also described.

\section{Organization and administration}

The organizational and administrative structures of DIS vary markedly, and this can have an important bearing on its independence and efficacy. DIS can be organized as a separate legal entity, or may be placed within a country's supervisory structure or under the jurisdiction of the national central bank, or other government ministry such as the Ministry of Finance or Department of Treasury. These categories are mutually exclusive - any DIS must be legally separate or located within the central bank, banking supervisor, or government ministry. Some DIS are organized as separate legal entities but are hosted within and supported by the central bank. We code such DIS as legally separate. . The variable Type is coded one if the DIS is legally separate, and two if it is contained within the central bank, banking supervisor, or government ministry.

Countries may choose an explicit DIS that is administered privately, publicly, or jointly through some combination of the two. For example, Germany's two statutory guarantee schemes have a mixed private/public component where they are privately administered but established in law and with public elements such as delegated public policy functions and oversight by the supervisory agency. This choice is often based on country-specific experience with historical banking failures and on whether private actors exist to potentially administer an explicit DIS (such as, for example, bankers' associations in Switzerland). Administration is coded one if the DIS is administered privately, two if it is administered publicly, and three if it is administered jointly. These categories are mutually exclusive. 


\section{Role}

While all explicit DIS must include a "paybox" function that provides payout to depositors in the event of bank failure, countries may also decide to combine the DIS function with resolution functions or that of banking supervisor or macro-prudential regulator, referred to as "paybox plus." Countries may also direct the DIS to minimize losses to the taxpayer, and provide it with the legal means to do so by granting DIS managers authority to create bridge banks, replace negligent bank managements, etc. Because the precise role of DIS schemes varies greatly worldwide, we classify DIS as paybox only or alternatively as a "paybox plus”, including loss or risk minimizer. These categories are mutually exclusive - DIS can either have a strict paybox role or have responsibilities beyond the paybox function. Role is coded one if the role of the DIS is paybox only, and two if it is a paybox plus, loss or risk minimizer.

\section{Multiple systems}

Some countries have multiple statutory deposit insurance schemes for different types of financial institutions. These can be of a public or private nature, and in some cases mean that effective coverage exceeds that stipulated under the national scheme. Multiple is coded one if multiple schemes exist within a country, and zero if otherwise. The footnotes to Table 3 provide details on the names of DIS active in the country, as well the institutions they cover when available. Our focus is the remainder of the paper is on the main statutory scheme in the country applying to private commercial banks.

\section{Participation}

In a world where finance has become increasingly globalized, differences in coverage among domestic banks and foreign bank entities operating in the same country have become increasingly important. For example, during the crisis in Iceland, deposits in foreign branches of Icelandic banks, which according to EC Directive were to be covered by the Icelandic DIS up to the statutory minimum of Euro 20,000, were initially not honored by Iceland. Domestic banks are generally covered by the DIS, but country schemes vary as to whether the locally-chartered subsidiaries or locally-domiciled branches of foreign banks are covered by the domestic DIS. Domestic banks equals one if domestic banks are covered, and zero otherwise. For some countries, such as the United States, the DIS does not base coverage on the home country of the foreign institution. Elsewhere, such as in EEA (European Economic Area) countries, the DIS extends coverage also to other countries but only within the EEA, with deposits in foreign branches being covered by the home-country deposit protection scheme of the bank and deposits in foreign subsidiaries being covered by the host-country deposit protection scheme. Deposits in branches of non-EEA banks are generally not covered by the EEA schemes. The variables

Foreign subsidiaries and Foreign branches equal one if the local subsidiaries or, respectively, local branches of any foreign banks are covered, and zero otherwise. 


\section{Types of deposits}

The DIS typically does not extend the same coverage to all types of deposits. The variable Foreign currency deposits takes the value one if the DIS covers deposits denominated in any other currency than the official domestic currency, and zero otherwise. For some countries, this may include all other currencies, while for others, a limited number of foreign currencies may be covered. For example, while the DIS within the EU cover deposits in any of the currencies of EU member states, not all cover deposits in currencies of non-EU member states. For example, the DIS in Austria, Belgium, Germany, Lithuania, and Malta do not cover deposits in non-EU currencies. Countries also may set different coverage limits for deposits in domestic or foreign currencies. In most cases, payments on foreign currency bank deposits, if covered, are made in local currency.

Coverage of interbank deposits is less common than that of retail deposits, as it is often assumed that financial institutions are better equipped to monitor the riskiness of the institutions in which they place deposits than small retail depositors. However, in times of financial market stress, interbank deposits may be guaranteed to encourage the free flow of liquidity across banks. The variable Interbank deposits is one if interbank deposits are covered, and zero otherwise. ${ }^{2}$

\section{Funding}

The primary function of a DIS is to prevent systemic bank runs. In order to do so, the DIS must be able to credibly claim that it can and will pay depositors in the event of bank failure. Countries can choose to fund potential payouts either ex ante or ex post. Most DIS with ex ante funding collect premiums on a scheduled basis, while ex post schemes collect funds from surviving institutions only when a covered bank fails and the available funds to cover depositors prove insufficient. These categories are mutually exclusive. Funding equals one if funding is ex ante and two if funding is ex post.

In addition to choosing between ex ante or ex post funding, DIS can also be funded by the government, privately by covered institutions, or jointly between the government and private actors. These categories are mutually exclusive. Countries such as Portugal with DIS primarily funded by participating banks that have had government funding provided are classified as funded jointly. Funding source is coded one if funding is by government, two if done privately, and three if done jointly. Government funding refers both to start-up and ongoing funding. In the case of ex post schemes, funding source refers to who pays the contributions to cover depositor payouts (typically the surviving banks). Backstop funding is considered separately in what follows. Depending upon a government's ability to collect taxes or issue new debt, governmentfunded schemes may credibly promise to address bank failures in a timely fashion, but they may

\footnotetext{
${ }^{2}$ In some countries, coverage could also exclude legal entities and central and local governments. We do not consider these exceptions.
} 
face internal pressure to avoid paying out taxpayer funds in the event of a large failure. Privatelyfunded schemes may encourage peer monitoring among institutions, but may more easily run short of available funds to credibly pay out depositors in the event of systemic failures.

\section{Government support}

While the primary funding mechanism of a DIS may not be the government, some countries provide contingency plans in the case of a shortfall of funds to cover deposits that include government support. For some countries, this takes the form of pre-approved credit lines from the Department of Treasury. For others, the DIS can issue bonds or receive loans guaranteed by the government. Backstop is coded one if in legislation or regulation any such form of government support in case of a shortfall of funds explicitly exists, and zero otherwise. Government support includes only support from the central government, not support from the central bank.

\section{Risk-adjusted premiums}

In addition to raising funds to cover future payouts, some DIS use differential premiums to curb risk-taking by financial institutions. Procedures for assessing risk vary across countries. For example, in Italy, banks are first grouped into six risk categories using four indicators of bank risk and performance. Then, these risk categories are mapped into six different levels of riskadjusted premiums. In Greece, starting in January 2009, annual premiums are adjusted by a risk coefficient that ranges between 0.9 and 1.1, as dictated by the bank's placement into one of three risk categories by the Bank of Greece. Risk assessment is based on measures of the bank's solvency, liquidity, and the efficiency of its internal control systems. Risk-adjusted premiums is coded one if premiums are adjusted for risk, and zero otherwise.

\section{Assessment}

Countries can choose to assess premiums on a variety of balance-sheet items. Assessment base denotes the base over which premiums are assessed. We classify the assessment base of premiums into four mutually exclusive categories - covered deposits, eligible deposits, total deposits, and total liabilities. Eligible deposits refers to deposits repayable by the deposit insurance scheme, before the level of coverage is applied, while covered deposits are obtained from eligible deposits when applying the level of coverage. The footnotes to Table 3 provide greater detail on the assessment base. For example, as stipulated by the Dodd-Frank Act the US FDIC changed the assessment base from total domestic deposits to average total assets minus tangible equity (i.e., Tier 1 capital), as a way to shift the balance of the cost of deposit insurance away from small banks to large banks that rely more on non-deposit wholesale funding.

\section{Payouts}

The most common form of DIS coverage is coverage at the "per depositor per institution" level. However, some countries cover deposits per depositor, or per depositor account. Coverage per 
depositor account is more generous than coverage per depositor per institution because it allows depositors to increase their effective coverage by opening multiple accounts within the same institution, while coverage per depositor per institution is more generous than coverage per depositor because it allows depositors to increase their effective coverage by placing deposits in multiple institutions. Some countries, such as the United States, have coverage per depositor per institution for individuals, but treat joint accounts separately from individual accounts, such that individual depositors with joint accounts can double their effective coverage (relative to the statutory limit) within the same institution. Payouts to depositors is coded one if the coverage is per depositor account, two if per depositor per institution, and three if per depositor. Table footnotes provide further details for countries with a more complicated structure.

Sometimes DIS have insufficient funds or otherwise impose losses on depositors (in nominal terms). We identify only three cases where substantial losses were imposed on insured deposits (including losses in nominal terms) despite the existence of explicit deposit insurance -Argentina (1989 and 2001), and Iceland (2008). ${ }^{3}$ Deposit losses is coded one for these countries, and zero otherwise. Further details about each episode are provided in the footnotes to Table 3.

\section{Banking crises}

We also collect information on whether the country experienced a banking crisis between 2007 and 2012. Banking crisis date denotes the year that the country experienced a banking crisis. Banking crisis dates for the period 2007-2011 are according to Laeven and Valencia (2012). Cyprus is added to this list as of 2012.

\section{Introduction of deposit guarantee scheme}

During the financial crisis period, several countries introduced explicit deposit insurance schemes (e.g., Australia and Singapore), or transitioned from unlimited government guarantees already in place before the onset of the crisis into an explicit DIS with capped coverage limits (e.g., Thailand). Introduction is coded one if the country introduced an explicit deposit insurance scheme during the period 2008-2013, and zero otherwise.

\section{Increase in statutory deposit coverage}

Many countries raised coverage limits during the crisis. For some, raising coverage was a result of ex ante decisions to index coverage limits to inflation-adjusted units, currency pegs, or measures of income such as a multiple of the minimum wage. For other countries, coverage limits were raised to discourage deposit outflows from the banking system. Within the EU in particular, policies emphasizing convergence and harmonization in deposit insurance coverage

\footnotetext{
${ }^{3}$ We do not consider losses on uninsured deposits, including eligible deposits above the coverage limit. For example, in March 2013, Cyprus imposed substantial haircuts on uninsured depositors in the country's two largest banks, which were assessed to be insolvent, and one of which was subsequently wound down.
} 
limits across countries resulted in large coverage increases. Other countries expanded the range of accounts covered to include foreign currency or interbank deposits. Increase in coverage is coded one if there was increase in coverage limits during the period 2008-2013, and zero otherwise. Table 4 specifies all countries that introduced temporary increases in coverage during the recent financial crisis.

\section{Abolishment of co-insurance}

In the pre-crisis period, co-insurance had gained popularity in some countries as a way to preserve the financial stability benefits of an explicit DIS, while preserving some of the monitoring incentives inherent in a system without formal coverage of deposits. With coinsurance, depositors are insured for only a pre-specified portion of their funds (i.e., less than 100 percent of their insured deposits).For example, in a country with 20 percent co-insurance and a maximum coverage limit of $\$ 100$, depositors with less than $\$ 125$ would receive 80 percent of the money within their account. Depositors with any amount greater than $\$ 125$ (where 80 percent is the maximum of $\$ 100$ ) would receive only $\$ 100$. During the crisis, this disciplining mechanism proved politically difficult to maintain. Sixteen countries had co-insurance in $2003-$ by 2010, only three remained. Coinsurance is coded one if co-insurance was abolished during the period 2008-2013, and zero otherwise.

\section{Government guarantee on deposits}

Alongside increases in the statutory coverage of deposits, several countries instituted a temporary unlimited guarantee on deposits. Government guarantee on deposits is coded one if a (partial or full) government guarantee on deposits was put in place during the period 2008-2013, and zero otherwise. Further details on specific deposit guarantees are provided in the footnotes to Table 5.

We distinguish between whether the deposit guarantee covered only some deposits (Limited) or all deposits (Full), and indicate the year when the guarantee was introduced (In place) and when the guarantee expired (Expired).

\section{Government guarantee on non-deposit liabilities}

In addition to providing extended coverage for deposit accounts, many countries that experienced a systemic banking crisis during the global financial crisis extended guarantees on the non-deposit liabilities of financial institutions. For some countries, the guarantees were limited to a small number of major institutions (Ireland). Other countries guaranteed specific debt classes, or only new debt issuances (Republic of Korea, United States), while others provided unlimited guarantees (Australia). Further details on the types of non-deposit guarantees are provided in the footnotes to Table 5. Guarantee on non-deposit liabilities is coded one if there were government guarantees applied to non-deposit liabilities during the period 2008-2013, and zero otherwise. 


\section{Government guarantee on bank assets}

In addition to guaranteeing bank deposits and other bank liabilities, some governments also resorted to guaranteeing particular asset classes of banks' balance sheets. For example, the governments of the Netherlands and Switzerland guaranteed the asset values of some hard-tovalue assets on the balance sheets of ING and UBS, respectively. Guarantee on bank assets is coded one if there were government guarantees on banking assets during the period 2008-2013, and zero otherwise.

\section{Significant nationalizations of banks}

Government intervention during the financial crisis also included the government taking control over financial institutions through nationalizations. Significant nationalization of banks is coded one if there was significant nationalization of banks and other financial institutions since 2008. Nationalizations are defined broadly to include explicit nationalizations as well as cases where the government takes control over financial firms through the acquisition of a majority ownership stake or by placing government-sponsored enterprises into receivership. ${ }^{4}$ We identify 17 countries where a significant portion of the financial system was nationalized since 2008 (including, for example, Belgium, Iceland, Ireland, the Netherlands, the United Kingdom, and the United States). While coverage limits may not have explicitly increased, nationalization implies an implicit government backstop of all deposits within these institutions (and a reduction in counterparty risk to these institutions for the rest of the financial system), as well as a contingent future liability for these national governments.

\section{Main Features of Deposit InSURAnCe Schemes ARound the WORLD}

The number of countries with explicit deposit insurance schemes has continued to increase. Out of 189 countries covered, 112 countries (or 59 percent) had explicit deposit insurance by yearend 2013, having increased from 84 countries (or 44 percent) in 2003. The 2008 global financial crisis contributed to this trend, with 5 countries adopting deposit insurance in the year 2008 alone. Australia, long an advocate of implicit deposit insurance, was a notable example among those countries that joined the ranks of those with explicit deposit insurance in 2008. Another force has been the EU-driven harmonization process of deposit insurance, which spurred the adoption of explicit deposit insurance throughout Central and Eastern Europe.

Deposit insurance is particularly widespread among high income countries. About 84 percent of countries with high incomes had explicit deposit insurance by year-end 2013. Israel and San Marino are notable exceptions among high income countries with implicit deposit insurance.

\footnotetext{
${ }^{4}$ For example, nationalizations of financial institutions in the United States include putting Fannie Mae and Freddie Mac into receivership and the government acquiring a majority stake in AIG.
} 
Explicit deposit insurance is less widespread among low income countries, at about 32 percent of countries (see Figure 1).

Similarly, there is regional variation in the existence of explicit deposit insurance. In Europe, almost all countries (or 96 percent of countries) have deposit insurance (the only two exceptions are Israel and San Marino). Explicit deposit insurance is less widespread in other parts of the world, with only 24 percent of countries in Africa having explicit deposit insurance (see Figure 2).

Deposit insurance schemes also vary markedly in how they are designed. Table 3 lists the main features of existing deposit insurance schemes, with countries listed alphabetically.

Most explicit deposit insurance schemes are pre-funded, an arrangement that is commonly described as an ex ante scheme, and contrasted with an ex post scheme. Ex ante schemes maintain a fund that typically receives and accumulates contributions from covered banks. Ex post schemes, on the other hand, collect premiums from surviving banks only if payouts from the scheme occur, i.e., if a bank is declared insolvent and depositors need to be reimbursed. Of all countries with explicit deposit insurance, 88 percent have an ex ante scheme (Figure 3). Ex post schemes exist in about one-fourth of high income countries but are altogether absent in low income and lower middle income countries. Notable examples are Austria, Chile, Italy, the Netherlands, Switzerland, and the UK. ${ }^{5}$

The purpose of many deposit insurance funds is simply to reimburse insured depositors in the event of bank insolvency. Such a fund is known as a paybox. Other funds have additional responsibilities, varying from licensing of banks, supervisory authority, and ability to collect information from banks. About 43 percent of all deposit insurance funds in ex ante schemes are a paybox, while the remaining 57 percent of funds have extended powers or responsibilities, including a responsibility to minimize losses or risks to the fund (Figure 4).

The majority of explicit schemes are legally separate from the central bank, banking supervisory agency, or ministry of finance, even though they may be "housed" within such institutions; only a minority of 14 percent of schemes is not legally separate from these government institutions (Figure 5). This number varies by income level, and is slightly higher in low income countries (27 percent).

Most deposit insurance schemes are administered publicly (about 66 percent of all schemes) but there is wide variation across countries' income levels. In low income countries, 82 percent of all schemes are administered publicly. In high income countries, on the other hand, only 44 percent

\footnotetext{
${ }^{5}$ In 2011, the Netherlands adopted a plan to transform its ex post DIS into an ex ante funded scheme with risk-based contributions. This transformation is scheduled to come into effect on July 1, 2015.
} 
of schemes are administered publicly, while 21 percent of schemes are administered privately (by covered banks), while the remaining 35 percent of schemes are administered jointly between the public and private sectors (Figure 6).

Funding of deposit insurance schemes derives primarily from contributions from the insured banks, although some schemes are funded in part or in whole by their government. Joint funding typically consists of start-up capital provided by the government with ongoing contributions from participating banks. 77 percent of all schemes are funded privately, while 2 percent of schemes are funded exclusively by the government, and the remaining 21 percent of schemes are funded jointly. However, there is substantial variation across countries, with 91 percent of schemes in high income countries being funded by the private sector (Figure 7).

Coverage limits also vary markedly across countries, both in absolute level and relative to per capita income, especially when other government guarantees are accounted for (see Table 2 and Figure 8). For example, statutory coverage limits range from a low of US\$460 in Moldova to highs of US\$250,000 in the United States, US\$327,172 in Norway, US\$1,523,322 in Thailand (where a blanket guarantee on deposits is being phased out), and full guarantees on deposits in Turkmenistan and Uzbekistan.

Figure 8 shows that coverage increased sharply during the recent financial crisis (in part reflecting the announcement of government guarantees on deposits) and was subsequently reduced, although coverage levels on average remain above pre-crisis levels. By end-2013, coverage limits on average amount to 5.3 times per capita income in high income countries, 6.3 times per capita income in upper middle income countries, 11.3 times per capital income in lower middle income countries, and 5.0 times per capita income in low income countries.

Co-insurance, while relatively common prior to the recent financial crisis, has almost disappeared as a feature of deposit insurance schemes, despite its loss-sharing appeal. The reason is that co-insurance rules were not enforced during the crisis to avoid imposing any losses on small depositors. It was feared that such losses might jeopardize depositor confidence and financial stability generally. Once the crisis abated, these co-insurance rules - having lost credibility - have not been reintroduced. While in 2003 a total of 16 deposit insurance schemes had co-insurance, this number dwindled to 3 by the end of 2013 (Figure 9). The only three remaining schemes with coinsurance are those of Bahrain, Chile, and Libya.

Adjusting deposit insurance premiums for risk, on the other hand, has been on the rise. By end2013, 31 percent of schemes adjusted premium contributions for risk (Figure 10). There is not much variation across income levels in the use of risk adjustments. Risk assessment methods varied widely across countries, though.

Many deposit insurance schemes (about 38 percent of all schemes) enjoy government backstops in case of a shortfall in funds, mostly in the form of credit lines or guarantees on debt issuances 
from the Treasury (Figure 11). The presence of such backstops is slightly higher in high income countries that tend to be in a better position to afford such guarantees (although this depends on the size of the financial sector in these countries).

\section{Depositor Protection During the Global Financial Crisis}

In an effort to contain the fallout from the global financial crisis, many countries expanded their financial safety net, both by increasing coverage of deposit insurance and by extending government guarantees to non-deposit liabilities (and in some cases on bank assets).

Figure 12 summarizes the increase in deposit protection since 2008, reporting the percentage of countries that either introduced an explicit deposit insurance scheme or expanded deposit protection in one of six ways: (a) increasing statutory coverage; (b) abolishing co-insurance; (c) introducing a government guarantee on deposits (either limited or full); (d) introducing a government guarantee on non-deposit liabilities; (e) introducing a government guarantee on bank assets; or (f) undertaking significant nationalizations of banks. We report these actions separately for crisis and non-crisis countries.

The expansion of the safety net was substantial, especially for crisis countries, and extended beyond traditional deposit insurance. Fourteen countries introduced explicit deposit insurance since 2008, and almost all countries with explicit deposit insurance that experienced a banking crisis over this period increased the statutory coverage limit in their deposit insurance scheme (96 percent of countries to be precise). Government guarantees on deposits were introduced in 32 percent of countries with deposit insurance and experiencing a banking crisis. 38 percent of these deposit guarantees were blanket guarantees, guaranteeing deposits in full. Government guarantees on bank liabilities were particularly widespread, especially among countries with deposit insurance experiencing a banking crisis (72 percent of these countries extended guarantees on bank liabilities). These guarantees varied from extending guarantees on debt issuances to blanket guarantees on all debt liabilities. Government guarantees on bank assets were used in 36 percent of countries with deposit insurance experiencing a banking crisis. Bank nationalizations were also widespread, occurring in 64 percent of countries with deposit insurance experiencing a banking crisis.

A number of insights can be gained from the crisis experience.

Together with central bank action in the form of extensive liquidity support and monetary easing, deposit insurance schemes contributed to preventing open bank runs. For example, extensive liquidity support to banks from the Federal Reserve combined with a credible fiscal backstop from the US Treasury to the FDIC prevented a generalized run from FDIC-insured bank deposits into currency. Federally uninsured savings in money market funds with reported a stable $\$ 1$ net asset value had a very different experience. Accounts in these funds became federally insured temporarily when the crisis intensified in September 2008. Money market funds experienced massive outflows (mainly into US banks) once it became publicly known (on September 16, 
2008) that the Reserve Primary Fund was in trouble. And in Europe, despite diverging macroeconomic fundamentals between the core and the periphery of the eurozone countries, insured bank deposits remained remarkably stable in most countries, with the exception of (1) isolated bank runs (Northern Rock in the UK and DSB Bank in the Netherlands) that were quickly contained, (2) a slow moving "run" on deposits in Greece on the back of growing fears of a euro breakup (total deposits declined by about 20 percent between 2010 and 2012), and (3) a generalized run in Cyprus where authorities had declared that a tax on insured deposits could be imposed (although this eventually did not materialize).

However, runs on uninsured deposits and non-deposit liabilities were widespread. For example, there was a significant run on wholesale deposits and a repo run on broker dealers in the US. These runs created severe stress in bank funding markets that had come to increasingly rely on short-term wholesale funding. This interconnectivity between banks and markets implies that funding shocks in capital markets can quickly spill over to banks and funding shocks to banks can spill over into capital markets, threatening the stability of the financial system and the real economy. The systemic risk that spillovers pose underscores the dangers of insuring wholesale deposits and deposit-like instruments and extending the perimeter of the financial safety net to nonbanks.

At the same time, many DIS were inadequately designed to stem the buildup of risk in the banking system either by nurturing market discipline or by seeking compensation for the risks being transferred to them. Co-insurance, a way to introduce market discipline, was largely phased out by most countries prior to the crisis. Nor did DIS premiums adequately reflect tail risk, effectively subsidizing potentially ruinous risk taking by banks. ${ }^{6}$ For example, about 97 percent of banks were assigned the lowest risk category in the US and were being charged a zero percent explicit premium for deposit insurance during the run-up to the crisis. And the majority of ex ante funds was small relative to the amount of insured deposits and was well below their target sizes.

To maintain public confidence in the banking system during the crisis, many countries raised deposit insurance coverage and introduced government guarantees on additional bank assets and liabilities. These measures generally seem to have had the intended beneficial short-run effect, although questions surfaced about the ability of some governments to honor their expanding obligations. For example, within the EU, national deposit insurance schemes nominally cover a minimum coverage limit determined at the EU level. Growing uncertainty emerged about the ability of peripheral European countries with sovereign debt problems to honor these obligations, causing some deposit flight to banks in countries with stronger sovereigns, such as Germany.

\footnotetext{
${ }^{6}$ The failure of DIS premiums to reflect tail risks does not necessarily reflect an inadequate design of DIS. It could also simply be a result of a general failure to assess financial sector risks.
} 
The issue is much broader though than that faced in these troubled economies. Many DIS appear underfunded, especially in countries with large financial systems. Table 5 highlights the imbalances between the ability to pay and potential liabilities from deposit insurance. The table contrasts the amount of coverage promised with the amounts of funds available (from bank contributions) and the government debt-to-GDP ratio, which we use as an inverse proxy for the ability of a government to expand its debt to backstop the DIS fund in individual countries. The size of the DIS fund seldom exceeds the percentage of deposits covered by DIS, leading one to wonder whether sufficient funds would be available to pay off depositors quickly in a large failed bank without resorting to additional public funding (see also Figure 13). More generally, the sizeable amounts of bank deposits relative to GDP combined with high levels of government indebtedness in some countries raise doubts about the ability of governments in these countries to backstop the financial safety net (Figure 14).

An additional complication that came to the fore during the crisis is the potentially different treatment of foreign and domestic depositors. For example, Iceland chose not to honor its deposit insurance obligations to foreign depositors when faced with a banking crisis at home. And in Europe, there are growing concerns especially among large corporate depositors about being "bailed in” during bank rescues.

To measure the generosity of the deposit insurance scheme and the existence of government guarantees on bank assets and liabilities, we create a safety net index, similar to the moral hazard index in Demirgüç-Kunt and Detragiache (2002).

The safety net index is computed using principal component analysis of standardized design feature variables that each are increasing in moral hazard. Specifically, we use the following design features: Coverage limit / GDP per capita and dummy variables for unlimited government guarantees in place, coverage of foreign currency deposits, coverage of interbank deposits, no co-insurance, payouts to depositors (per deposit account=2; per depositor per institution=1; per depositor=0), no risk-adjusted premiums, ex ante fund, funded by government, backstop from government, no losses imposed on uninsured deposits, government guarantees on bank deposits (limited or full), government guarantees on non-deposit liabilities since 2008, and government guarantees on bank assets since 2008. Each of these variables is constructed such that higher values denote more generosity or greater government support and imply more moral hazard. This set expands the set of deposit insurance variables used by Demirgüç-Kunt and Detragiache (2002) by including information on government guarantees in the financial sector. As such, the index captures moral hazard generated by the financial safety net at large, not deposit insurance in a strict sense. The safety net index (SNI) is the sum of the first six principal components for which the eigenvalues exceed 1.

Figure 16 reports the values of our SNI index, with higher values denoting more generosity, and consequently more moral hazard. We observe much country variation in the SNI index. It ranges from lows of -11.9 in Argentina and -10.5 in Iceland (which both have imposed losses on insured 
depositors) to highs of 4.6 in Ireland and the United States (both of which issued temporary guarantees on deposits and non-deposit liabilities during the recent crisis) and 4.5 in Turkmenistan and 7.8 in Uzbekistan (both of which have blanket guarantees). Some of these countries will be able to fund such generous safety nets promises, but the fairness and efficiency of imposing such a burden on households and nonfinancial firms is questionable. And the moral hazard it creates is hard to contain as evidenced in the difficulty of eliminating the too big to fail problem.

Going forward, important questions remain about how to restore market discipline. The problem is the perverse incentives generated by expectations that in future crises authorities will adopt the same policies of increasing coverage and creatively expand the financial safety net even further. Expectations that bailouts will again be the tool of choice in future crises complicate the role and effectiveness of deposit insurance limitations.

Academic research prior to the crisis generally advocated a limited role for deposit insurance, underscoring the moral hazard incentives associated with overly generous coverage. Concerns about moral hazard led to policy recommendations for low coverage-to-income limits, coinsurance schemes, and the exclusion of wholesale deposits (e.g., Demirgüç-Kunt and Detragiache, 2002, and Demirgüç-Kunt and Huizinga, 2004).

Using data on deposit insurance design features before the recent global financial crisis, Anginer, Demirgüç-Kunt, and Min (2014) examine the relation between deposit insurance, bank risk, and systemic fragility across a large number of countries in the years leading to and during the crisis. They show that generous financial safety nets increase bank risk and systemic fragility in the years leading up to the crisis (the moral hazard effect), however during the crisis, bank risk is lower and systemic stability is greater in countries with deposit insurance coverage (the stabilization effect). Consistent with the earlier literature, they find that the overall effect of deposit insurance over the full sample remains negative, suggesting that the destabilizing effect due to moral hazard is greater in magnitude compared to its stabilizing effect during periods of financial turbulence.

However, less attention was paid to the political economy problems that plague deposit insurance at times of a crisis. ${ }^{7}$ When faced with a crisis, governments quickly rewrote existing statutes so that DIS managers worldwide could increase coverage limits, abolish coinsurance, and extend guarantees on non-deposit liabilities. Because this kind of support is funded as a contingent liability, neither the DIS nor the national governments felt an immediate fiscal repercussion. These actions could be performed easily and quickly in the name of financial stability. None of these increases in potential liabilities passed through official government budgets. And because

\footnotetext{
${ }^{7}$ What Kane (1989) calls the "proliferation of hopelessly insolvent zombie institutions simultaneously gambling for resurrection."
} 
they were not accompanied by increased premiums or other measures to rein in risk-taking by the insured (such as ex post levies on banks), the banks being rescued did not complain either. The problem is that these political economy considerations are not symmetric. Once in place, it is politically very hard to unwind guarantees and especially difficult to decrease DIS coverage, when and as a crisis abates. And while premiums can be gradually increased on banks to recoup part of the subsidy passed through the financial safety net from the bailout policies, the problem is that it is never easy to recoup these costs only from surviving banks who often have even more political clout than before the crisis occurred. Their clout helps to persuade authorities to hold post-crisis premiums below actuarially fair levels, not only to lower the burden on the banks, but to support credit growth and macroeconomic recovery.

Some would argue that a gradual move to bail-in policies to replace the bail-out of senior uninsured debtholders and uninsured depositors would protect against contingent liabilities for governments arising from the financial safety net. Indeed, several countries have made steps in this direction by adopting rules that would impose losses on such private creditors in the event of a bank failure. The problem with these rules is that they are time inconsistent: the temptation to renege on bail-in policies in the midst of a systemic crisis, when creditor panic and contagion risk rises to dangerous levels, will be too high for many governments.

The evidence also implies that it is difficult to use a DIS as a source of monitoring and market discipline during a systemic banking crisis. In the years leading up to the financial crisis, many countries had chosen prudently low levels of deposit coverage and/or introduced explicit coinsurance in an attempt to encourage monitoring of financial institutions by retail depositors and by one another. In 2003, many countries had co-insurance, but by 2013, only three countries did. The evidence indicates that the explicit coverage limits that are set in normal times are not time-consistent. This is particularly problematic in environments with weak frameworks for resolving the affairs of insolvent financial firms. In such countries, regulators and supervisors cannot readily ignore budgetary and political pressures to intervene in distressed banks. It is therefore important for governments to monitor, assess, and report fiscal risks related to DIS. In the wake of the crisis, the size of explicit government contingent liabilities imbedded in government safety nets and the probability of these contingent liabilities materializing have both increased.

\section{CONCLUding RemarKs}

Deposit insurance, long a topic for narrow specialists, became a hot policy topic during the global financial crisis. Countries that could afford to do so broadened deposit insurance coverage and enlarged their financial safety net to restore confidence in their financial system. Only a few less fortunate countries broke their promises on insured deposits (as in the case of Iceland) or imposed substantial losses on uninsured depositors (as in the case of Cyprus). 
This paper presents a comprehensive database of features of existing deposit insurance arrangements and government guarantees on bank assets and liabilities, together with a preliminary analysis of the effectiveness of these arrangements during the global financial crises.

This analysis suggests that deposit insurance arrangements were largely effective in preventing large-scale depositor runs, but have never correctly priced risk. This underpricing of deposit insurance is at least as likely to encourage potentially ruinous risk taking by banks in the future as it has in the past. The expansion of the safety net during the crisis intensifies questions about the ability of countries to honor their obligations and about moral hazard going forward.

At the same time, the increasing reliance on short-term wholesale funding for banks and their links to securities, futures, and derivatives markets raise doubts about whether the government should also protect deposit-like instruments to prevent runs on wholesale funding to spill over to traditional banking markets. A generous safety net raises deep problems that must not be ignored: concerns about moral hazard, distributional fairness, and ability to pay. These concerns are apt to be particularly pressing in countries whose financial systems are large relative to the size of their economy.

A gradual move to bail-in policies of uninsured depositors and debtholders would help ensure that governments are able to honor payments out of generous DIS, though contagion concerns, too big to fail considerations, and other political economy constraints may get in the way of efforts to bail in such creditors during a systemic crisis.

A more comprehensive analysis of these issues is needed and we hope that publishing this database will facilitate such research. 


\section{REFERENCES}

Anginer, D., A. Demirgüç-Kunt, and M. Zhu, 2014, “How Does Deposit Insurance Affect Bank Risk? Evidence from the Recent Crisis,” Journal of Banking and Finance; also World Bank Policy Research Paper, WPS6289.

Basel Committee on Banking Supervision (BCBS) and International Association of Deposit Insurers (IADI), 2009, “Core Principles for Effective Deposit Insurance Systems,” https://www.bis.org/publ/bcbs156.pdf

Blinder, A.S., and R.F. Wescott, 2001, "Reform of Deposit Insurance: A Report to the FDIC," FDIC and Princeton University. Mimeo.

http://www.fdic.gov/deposit/insurance/initiative/reform.html

Demirgüç-Kunt, A., and E. Detragiache, 2002, "Does Deposit Insurance Increase Banking System Stability? An Empirical Investigation,” Journal of Monetary Economics, Vol. 49, No. 7, pp. 1373-1406.

Demirgüç-Kunt, A., and H. Huizinga, 2004, “Market Discipline and Deposit Insurance,” Journal of Monetary Economics, Vol. 51, No. 2, pp.375-399.

Demirgüç-Kunt, A., B. Karacaovali, and L. Laeven, 2005, “Deposit Insurance around the World: A Comprehensive Database,” Policy Research Working Paper No. 3628 (Washington, DC: World Bank).

Demirgüç-Kunt, A., E.J. Kane, and L. Laeven, 2008a, “Determinants of Deposit-Insurance Adoption and Design,” Journal of Financial Intermediation, Vol. 17, No. 3, pp. 407-438.

Demirgüç-Kunt, A., E.J. Kane, and L. Laeven (Eds.), 2008b, Deposit Insurance around the World: Issues of Design and Implementation (Cambridge, MA: MIT Press).

European Commission, 2004, Report on minimum guarantee level of Deposit Guarantee Schemes Directive 94/19/EC, http://ec.europa.eu/internal_market/bank/docs/guarantee/report_en.pdf. Annex available from: http://ec.europa.eu/internal_market/bank/docs/guarantee/annexes_en.pdf

European Commission, 2010, Impact Assessment for Proposal on Deposit Guarantee Schemes, http://ec.europa.eu/internal_market/bank/docs/guarantee/20100712_ia_en.pdf. Annex II available from: http://ec.europa.eu/internal_market/bank/docs/guarantee/jrcannex2_en.pdf

European Commission, 2011, JRC Report under Article 12 of Directive 94/19/EEC, http://ec.europa.eu/internal_market/bank/docs/guarantee/jrc-rep_en.pdf. Annex I and II 
available from: http://ec.europa.eu/internal_market/bank/docs/guarantee/jrcannex1_en.pdf and http://ec.europa.eu/internal_market/bank/docs/guarantee/jrcannex2_en.pdf.

European Federation of Deposit Insurance, 2006, Deposit Guarantee Systems: EFDI’s First Report, http://efdi.eu/fileadmin/user/publications/EFDI\%20publications/Deposit\%20Guarantee\% 20Systems\%20EFDIs\%20First\%20Report\%20\%28Manuela\%20De\%20Cesare\%202006 \%29.pdf

Financial Stability Board, 2012, Thematic Review on Deposit Insurance Systems, http://www.financialstabilityboard.org/publications/r_120208.pdf

Financial Stability Board, 2010, Update on Unwinding Temporary Deposit Insurance Arrangements, http://www.financialstabilityboard.org/publications/r_1006.pdf

Garcia, G., 2000, Deposit Insurance: Actual and Good Practices, IMF Occasional Paper No. 197 (Washington, DC: International Monetary Fund).

International Association of Deposit Insurance, 2008, 2008 Annual Survey Results of Deposit Insurance, http://www.iadi.org/Research.aspx?id=58

International Association of Deposit Insurance, 2010, 2010 Annual Survey Results of Deposit Insurance, http://www.iadi.org/Research.aspx?id=58

International Association of Deposit Insurance, 2011, 2011 Annual Survey Results of Deposit Insurance, http://www.iadi.org/Research.aspx?id=58

Kane, E.J., 1989, The S\&L Insurance Mess: How Did it Happen? (Washington, DC: The Urban Institute Press).

Laeven, L., 2013, European Union: Publication of Financial Sector Assessment Program Documentation-Technical Note on Deposit Insurance, IMF Country Report No. 13/66 (Washington, DC: International Monetary Fund). http://www.imf.org/external/pubs/ft/scr/2013/cr1366.pdf

Laeven, L., and F. Valencia, 2012, “Systemic Banking Crises Database: An Update,” IMF Working Paper no. 12/163 (Washington, DC: International Monetary Fund). http://www.imf.org/external/pubs/ft/wp/2012/wp12163.pdf 
Schich, S., 2008, "Financial Crisis: Deposit Insurance and Related Safety Net Aspects,” Financial Market Trends, OECD. http://www.oecd.org/finance/financialmarkets/41894959.pdf

Schich, S., 2009, “Expanded Guarantees for Banks: Benefits, Costs, and Exit Issues,” Financial Market Trends, OECD. http://www.oecd.org/finance/financial-markets/42779438.pdf

Schich, S., and B.-H. Kim, 2011, Guarantee Arrangements for Financial Promises: How Widely Should the Safety Net Be Cast? Financial Market Trends, OECD. http://www.oecd.org/finance/financial-markets/48297609.pdf

World Bank, 2003, Survey of Banking Supervision and Regulation, http://siteresources.worldbank.org/INTRES/Resources/4692321107449512766/Caprio_2003_banking_regulation_database.xls

World Bank, 2011, Survey of Banking Supervision and Regulation, http://siteresources.worldbank.org/EXTGLOBALFINREPORT/Resources/88160961346865433023/8827078-1347152290218/Bank_Regulation.xlsx 
Figure 1. Explicit Deposit Insurance by Income Group, 2013

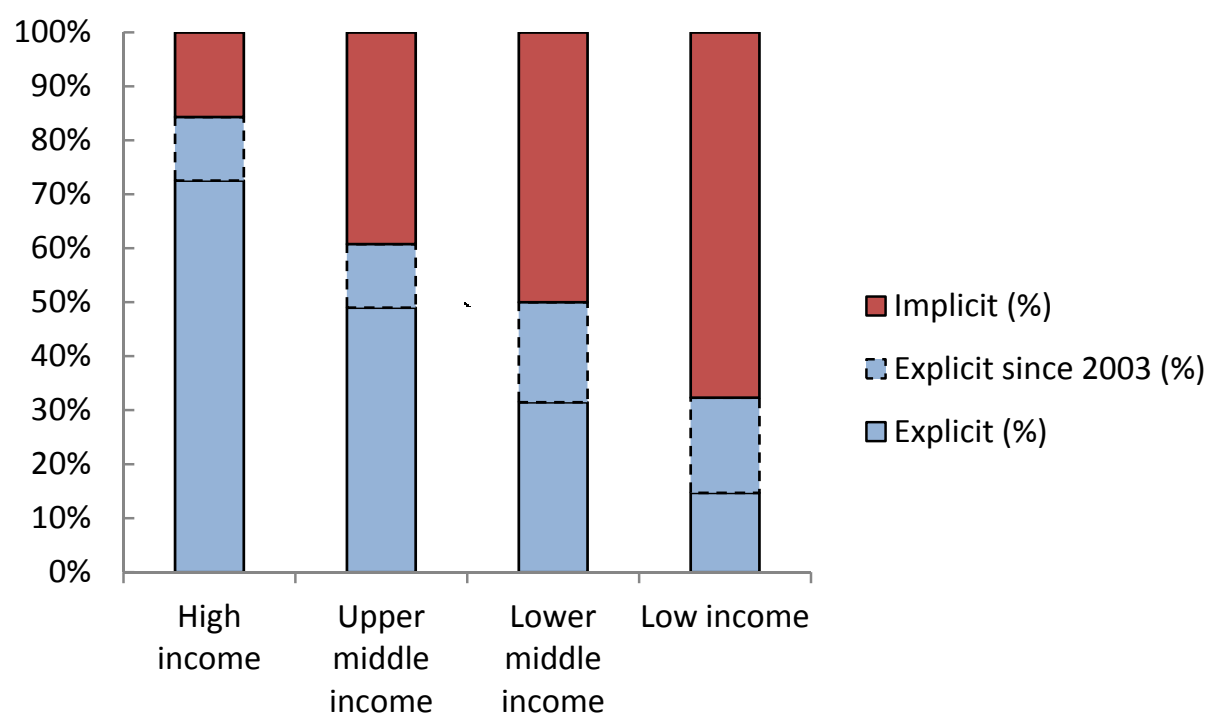

Figure 2. Explicit Deposit Insurance by Region, 2013

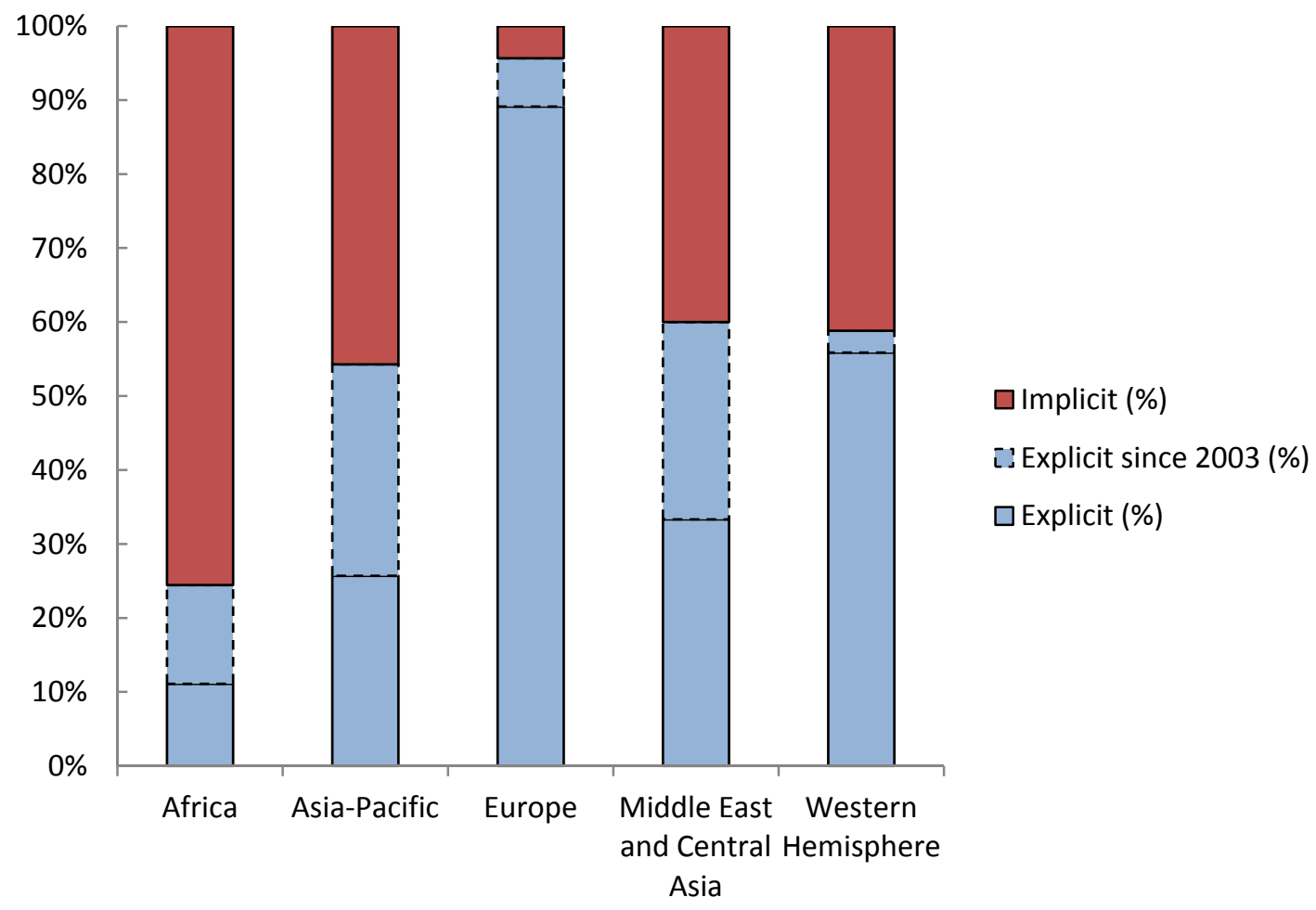


Figure 3. Type of DI Scheme, 2013

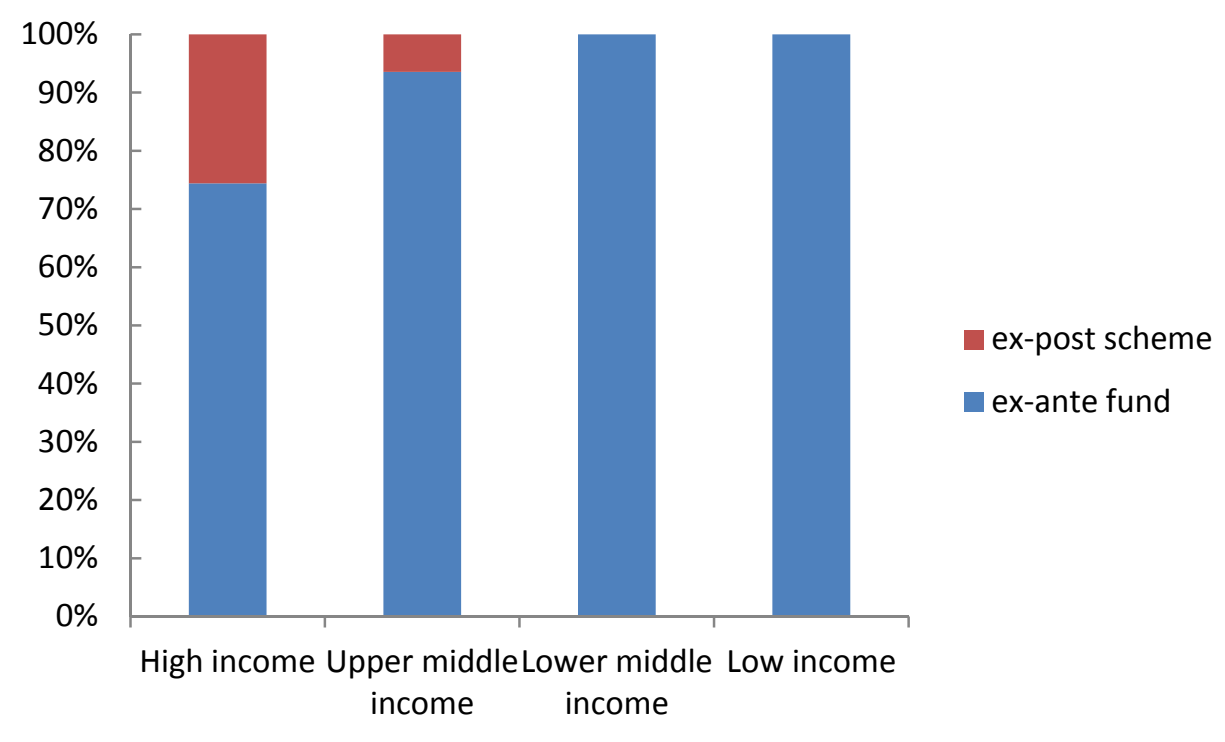

Figure 4. Objective of the DI Scheme, 2013

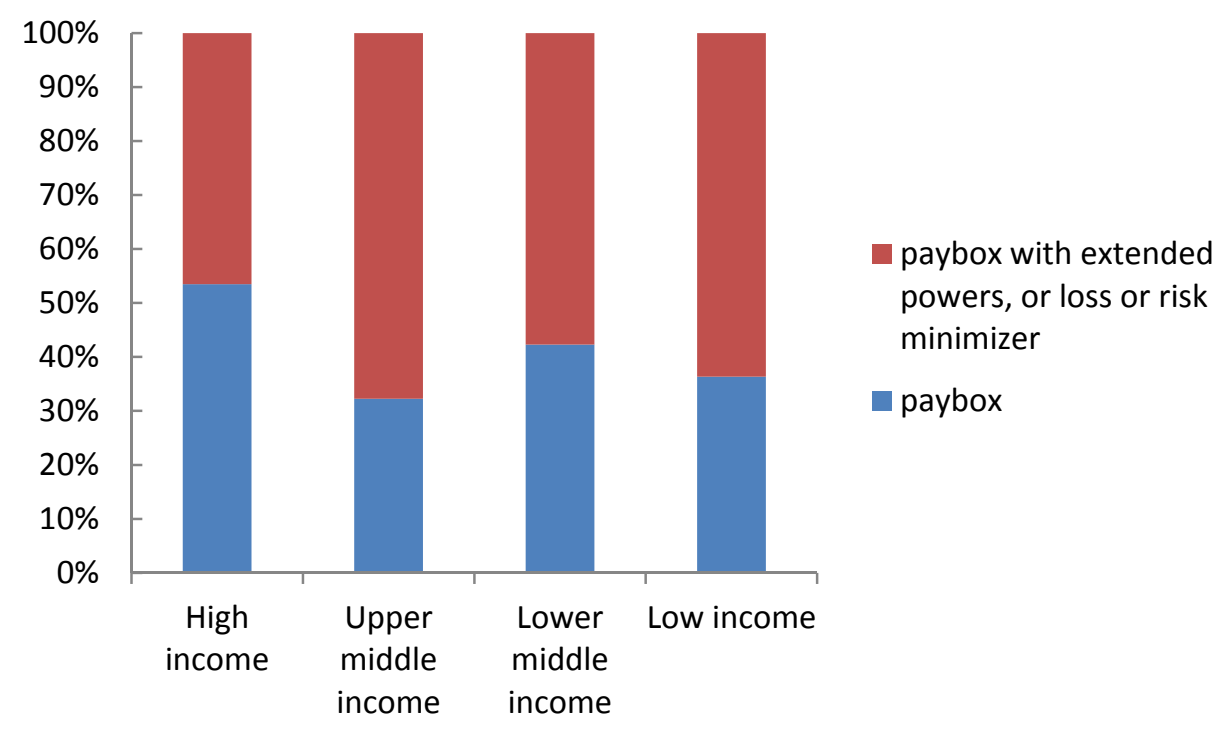


Figure 5. Organization of the DI Scheme, 2013

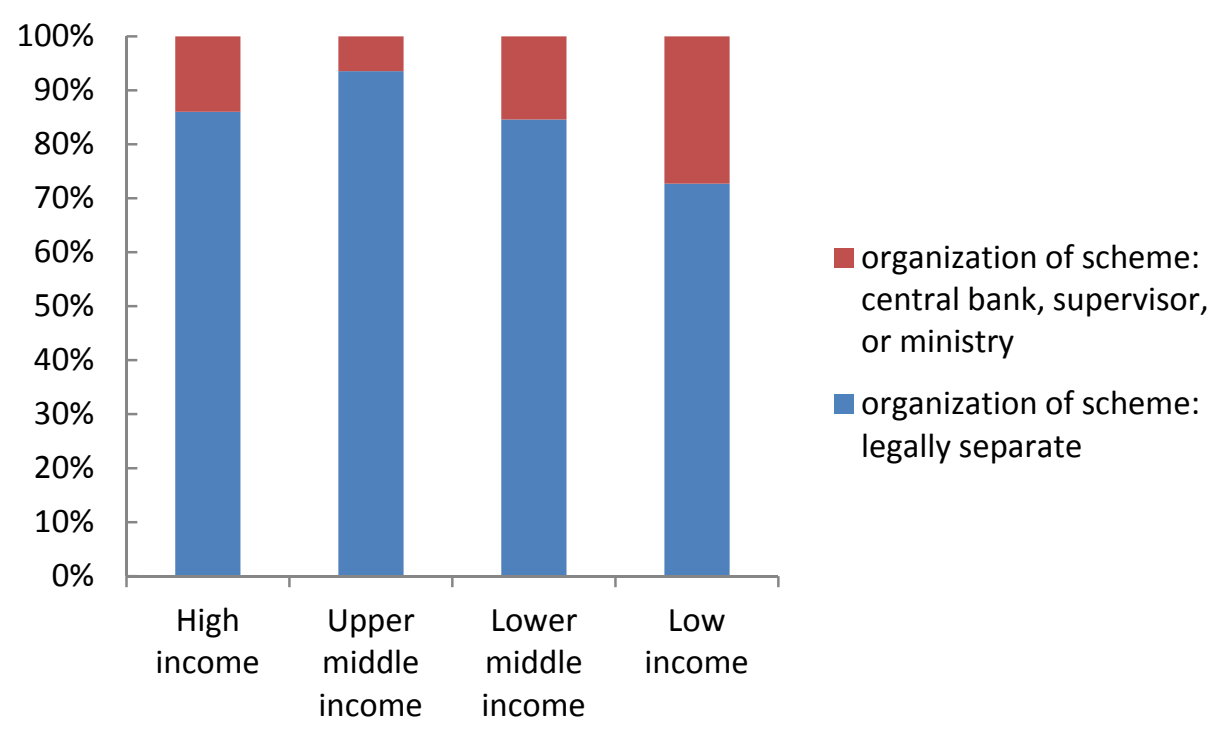

Figure 6. Administration of the DI Scheme, 2013

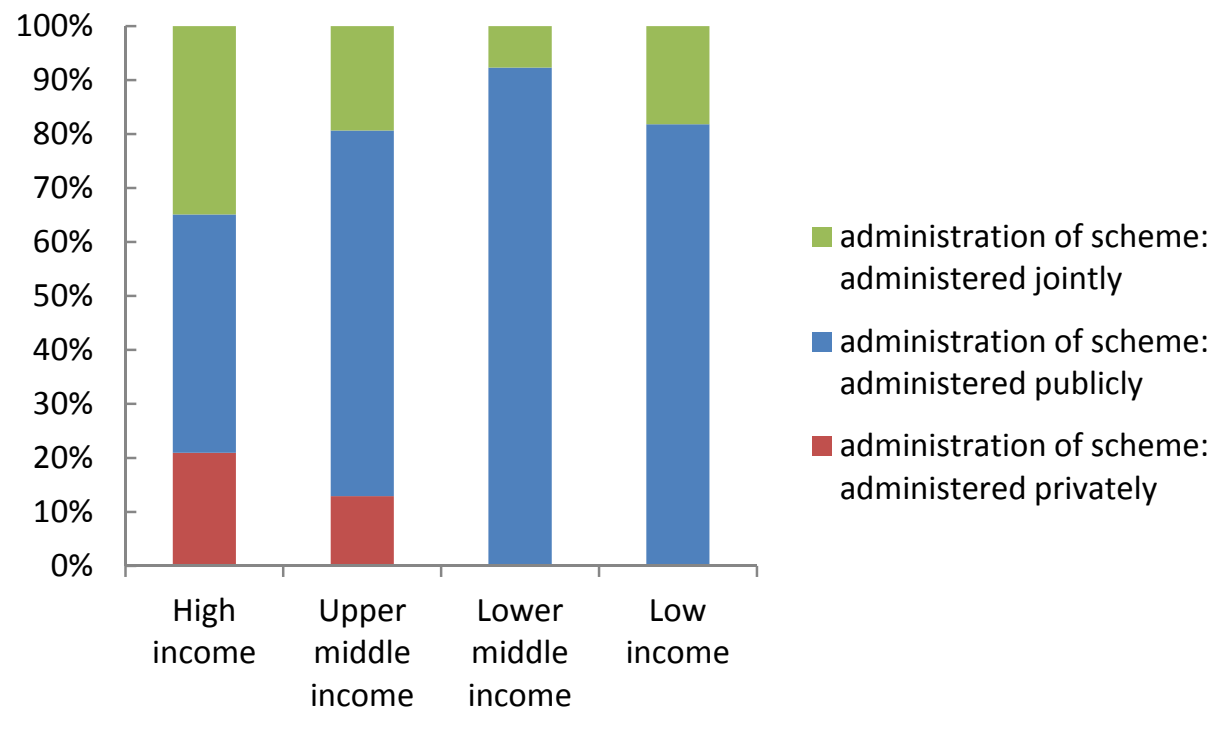


Figure 7. Funding of the DI Scheme, 2013

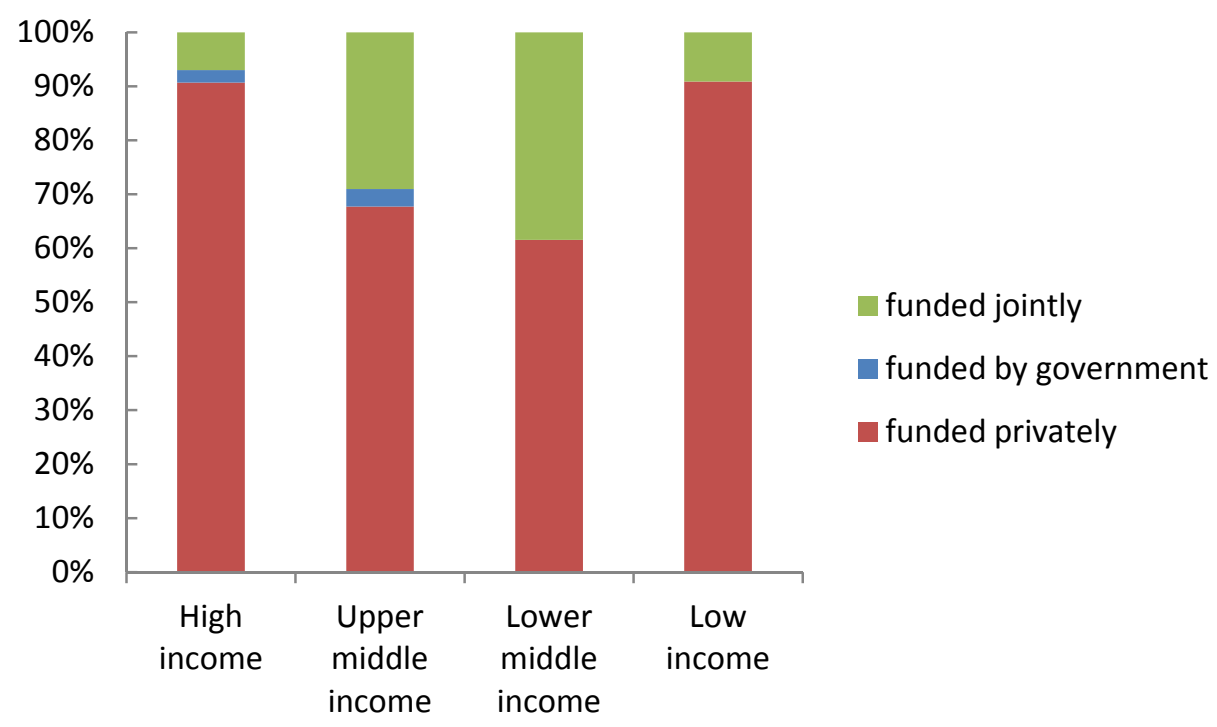

Figure 8. Coverage Increased During Crisis and Remains Above Pre-Crisis Levels

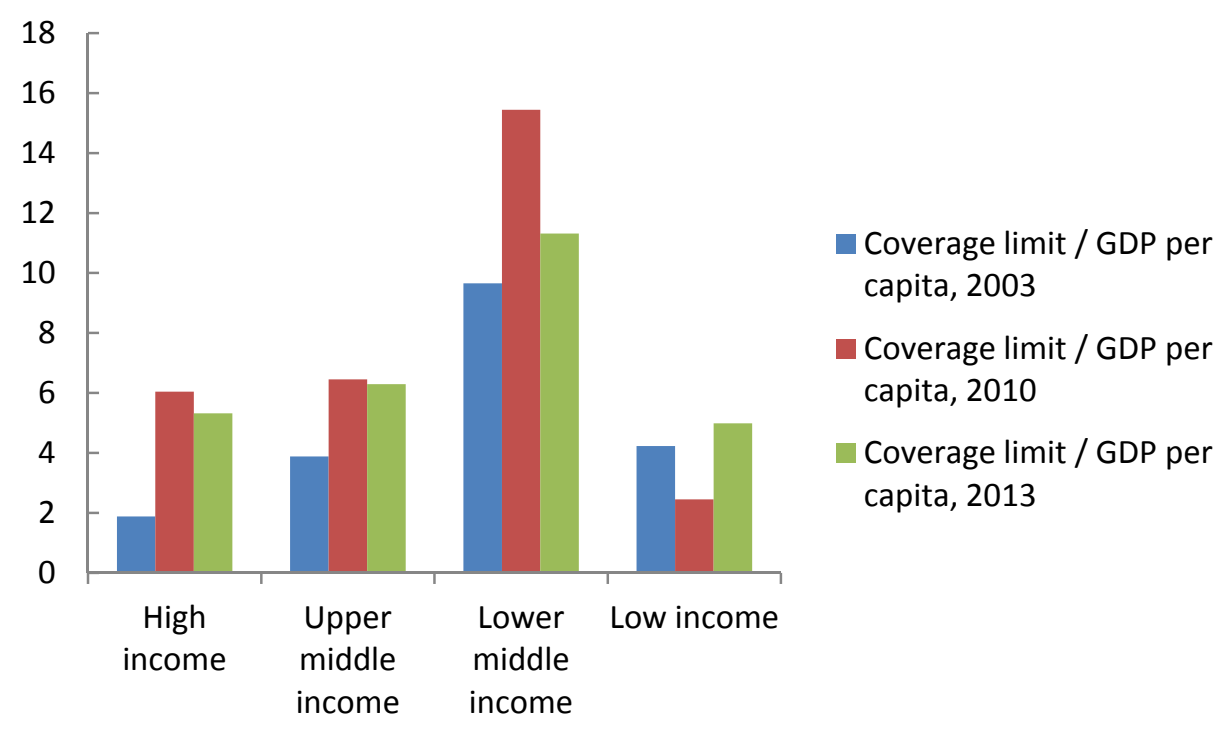


Figure 9. Decline of Coinsurance, 2003-2013

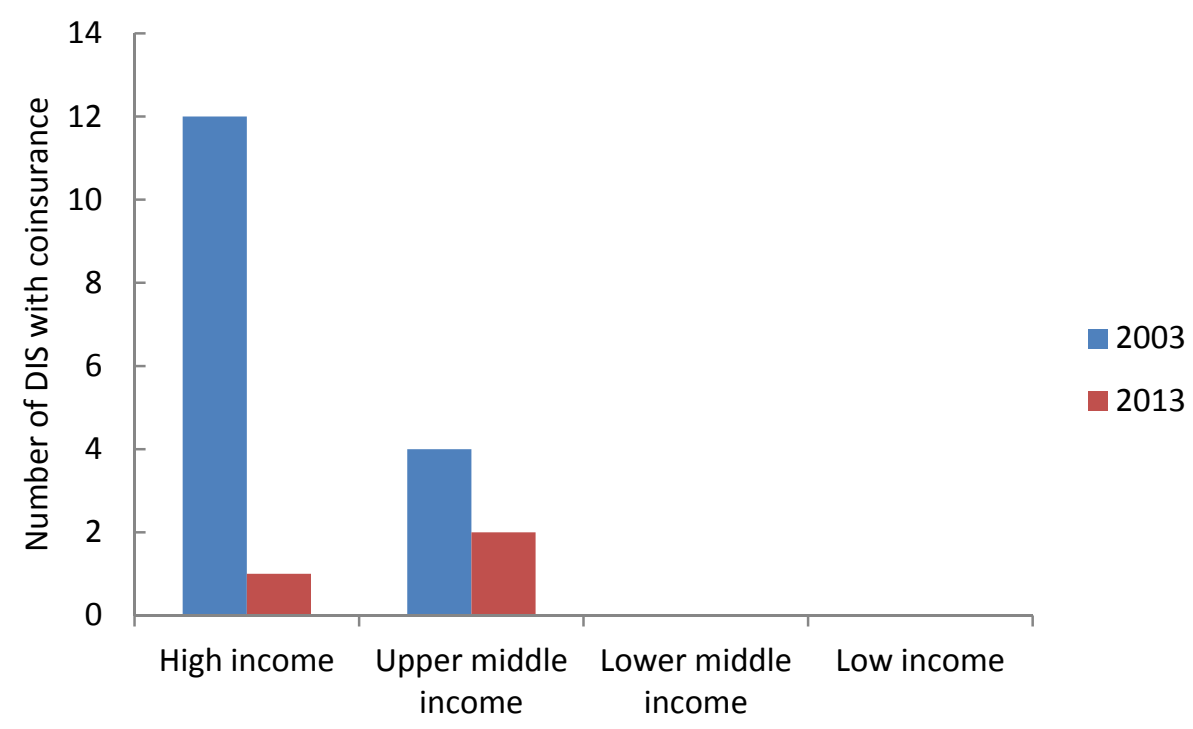

Figure 10. Risk Adjustment of DI Premiums, 2013

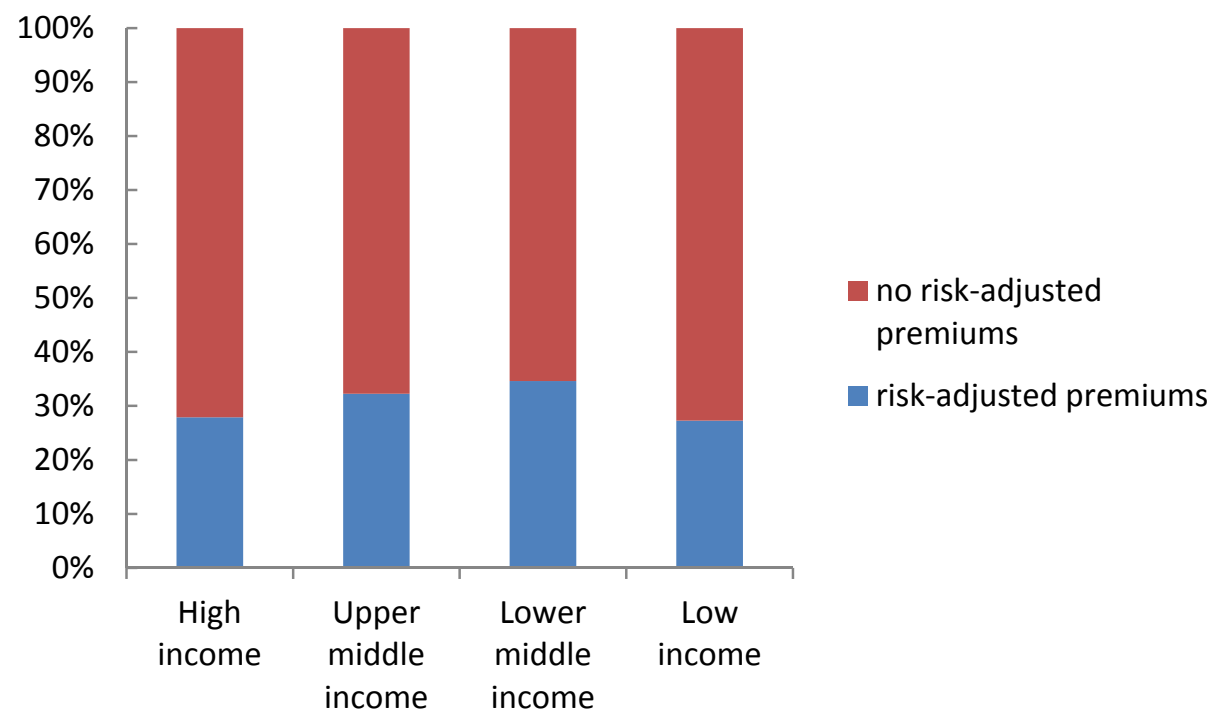


Figure 11. Government Support of DI Schemes, 2013

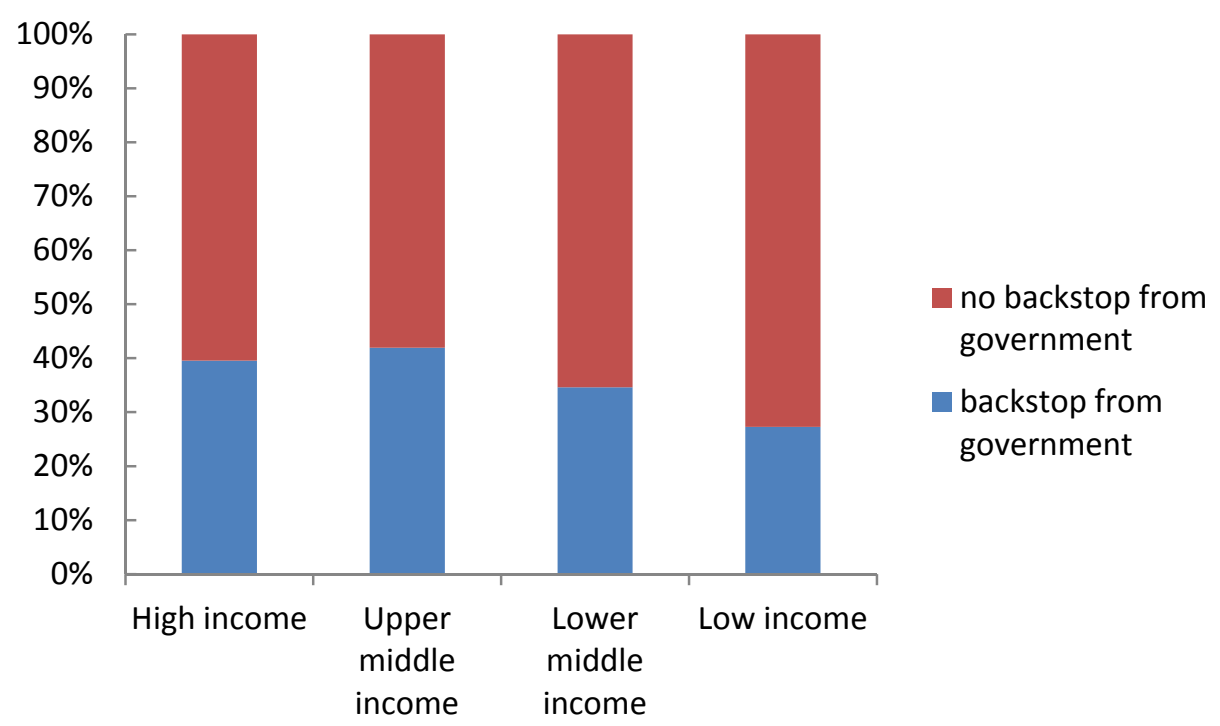

Figure 12. Increase in Depositor Protection, 2007-2013

$\%$ of countries with explicit DIS

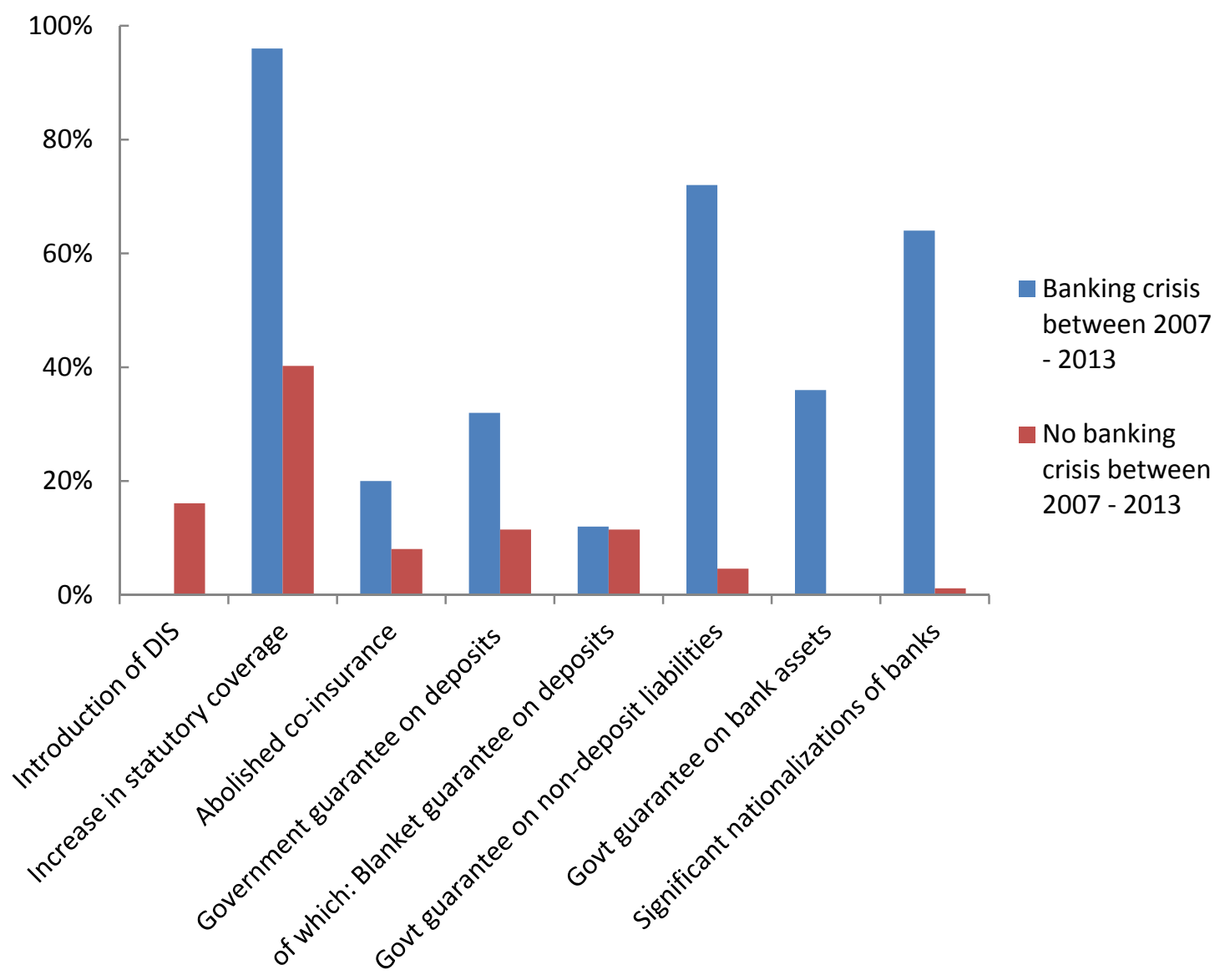


Figure 13. Potential Deposit Liabilities and Ability to Pay by the DIS Fund, end-2010 1/

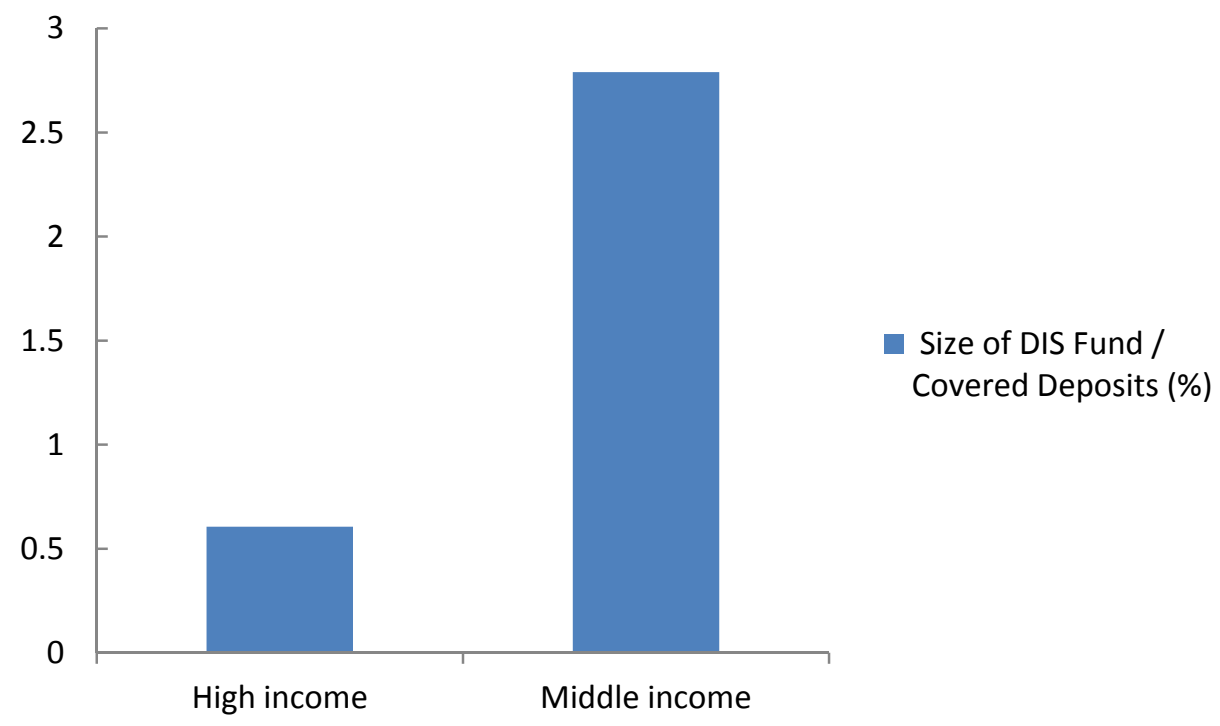

1/ Middle income includes lower and upper middle income countries. Insufficient data to report figures on low income countries.

Figure 14. Total Deposits and Ability to Pay by the Government, end-2010 1/

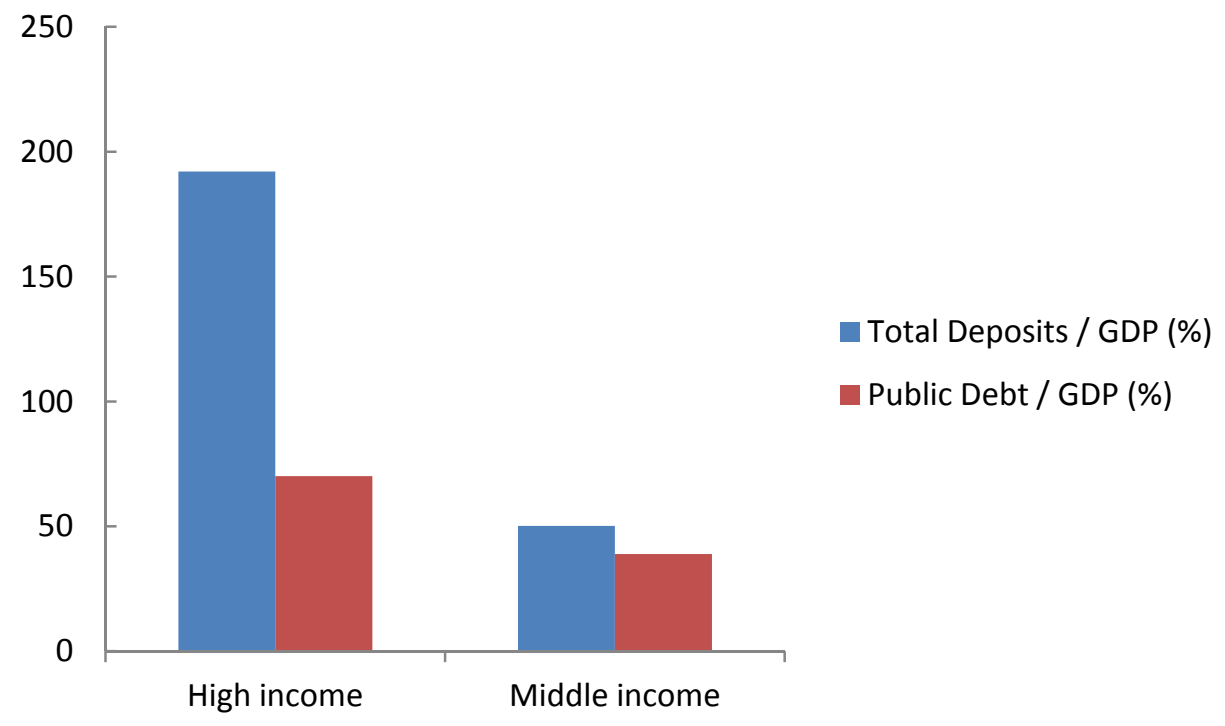

1/ Middle income includes lower and upper middle income countries. Insufficient data to report figures on low income countries. 
Figure 15. Size of DIS Fund Relative to Covered Deposits and Government Indebtedness

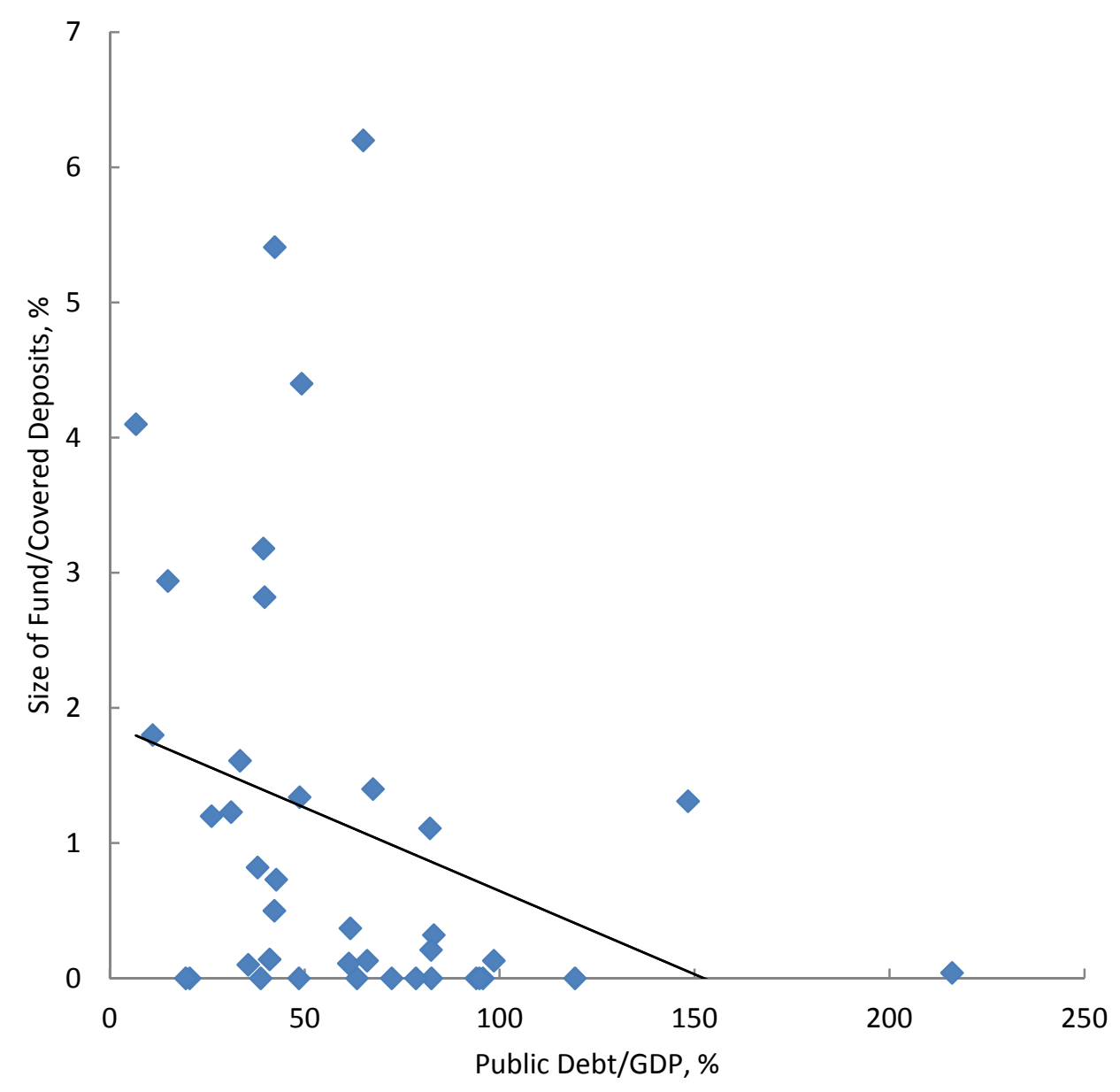


Figure 16. Safety Net Index, $20131 /$

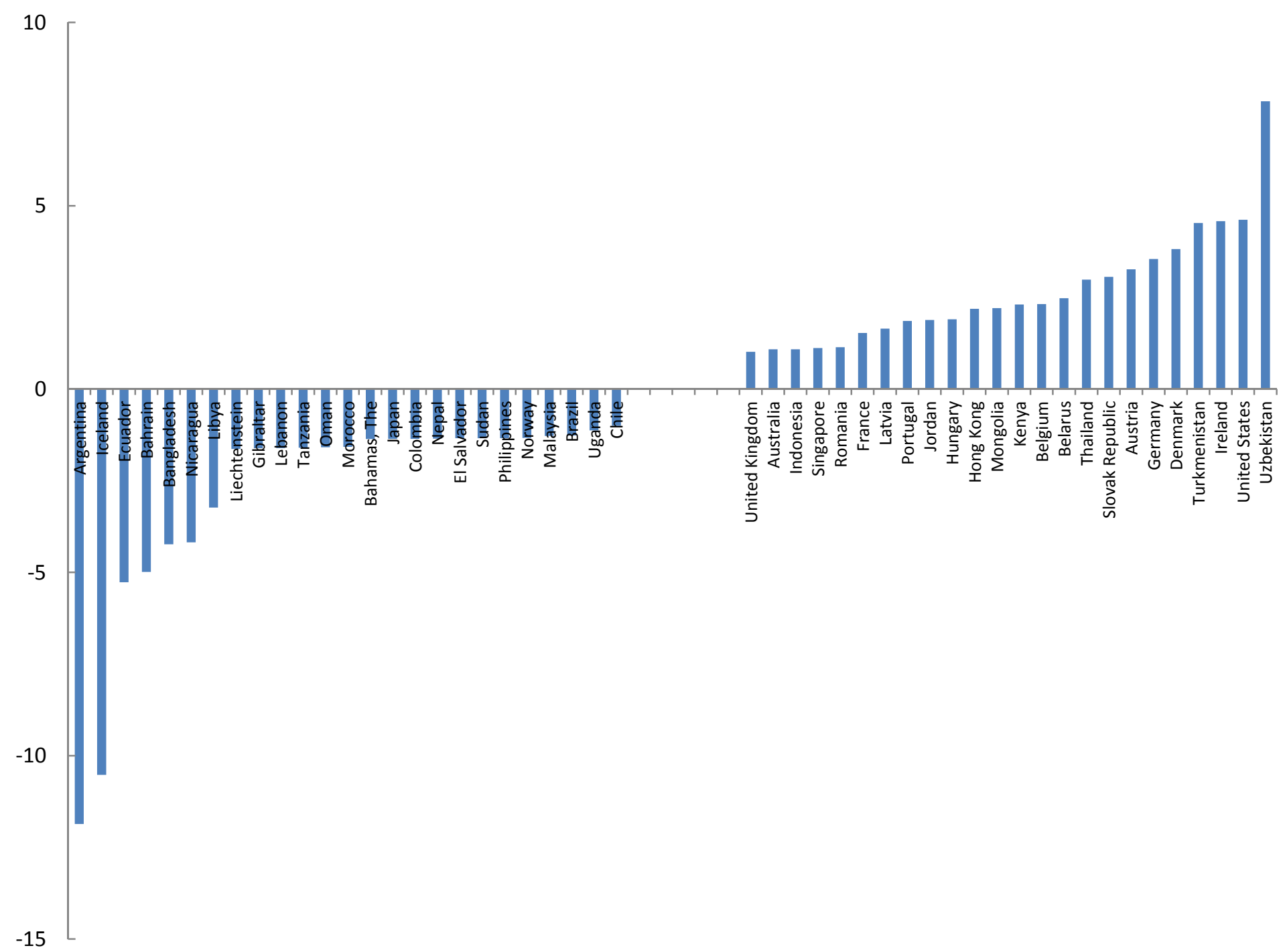

Notes: The safety net index is a principal components index of DI design and other safety net features that is increasing in the generosity of the safety net. 1 / Countries with safety net index (SNI) values between -1 and +1 are excluded from the chart. 
Table 1. Explicit Deposit Insurance Schemes Around the World, end-2013

\begin{tabular}{|c|c|c|c|c|c|c|}
\hline \begin{tabular}{|l|} 
As of 2013 \\
\end{tabular} & \multicolumn{3}{|c|}{ Countries with Explicit Deposit Insurance Schemes } & \multicolumn{3}{|c|}{ Countries Without Explicit Deposit Insurance Schemes } \\
\hline (2) & $\begin{array}{l}\text { Cameroon (2011) 7/ } \\
\text { Central African Rep. (2011) } \\
\text { Chad (2011) 7/ } \\
\text { Congo, Rep. (2011) 7/ } \\
\text { Equatorial Guinea (2011) 7/ } \\
\text { Gabon (2011) 7/ } \\
\text { Kenya } \\
\text { Nigeria } \\
\text { Tanzania } \\
\text { Uganda } \\
\text { Zimbabwe }\end{array}$ & & & $\begin{array}{l}\text { Angola } \\
\text { Benin } \\
\text { Botswana } \\
\text { Burkina Faso } \\
\text { Burundi } \\
\text { Cape Verde } \\
\text { Comoros } \\
\text { Congo, Democratic Rep. } \\
\text { Côte d'Ivoire } \\
\text { Eritrea } \\
\text { Ethiopia } \\
\text { Gambia, The }\end{array}$ & $\begin{array}{l}\text { Ghana } \\
\text { Guinea } \\
\text { Guinea-Bissau } \\
\text { Lesotho } \\
\text { Liberia } \\
\text { Madagascar } \\
\text { Malawi } \\
\text { Mali } \\
\text { Mauritius } \\
\text { Mozambique } \\
\text { Namibia } \\
\text { Niger }\end{array}$ & $\begin{array}{l}\text { Rwanda } \\
\text { São Tomé and Príncipe } \\
\text { Senegal } \\
\text { Seychelles } \\
\text { Sierra Leone } \\
\text { Somalia } \\
\text { South Africa } \\
\text { Swaziland } \\
\text { Togo } \\
\text { Zambia }\end{array}$ \\
\hline Asia-Pacific 9/ & $\begin{array}{l}\text { Australia (2008) 1/ } \\
\text { Bangladesh } \\
\text { Brunei Darussalam (2011) 1/ } \\
\text { Hong Kong (2004) 1/ } \\
\text { India } \\
\text { Indonesia (2004) 1/ } \\
\text { Japan }\end{array}$ & $\begin{array}{l}\text { Korea, Rep. of } \\
\text { Laos } \\
\text { Malaysia (2005) /1 } \\
\text { Marshall Islands 2/ } \\
\text { Micronesia 2/ } \\
\text { Mongolia (2013) 1/ } \\
\text { Nepal (2010) 1/ } \\
\end{array}$ & $\begin{array}{l}\text { Philippines } \\
\text { Singapore (2006) 1/ } \\
\text { Sri Lanka (2012) 8/ } \\
\text { Thailand (2008) 1/ } \\
\text { Vietnam }\end{array}$ & $\begin{array}{l}\text { Bhutan } \\
\text { Cambodia } \\
\text { China } \\
\text { Fiji } \\
\text { Kiribati } \\
\text { Maldives } \\
\text { Myanmar 3/ } \\
\end{array}$ & $\begin{array}{l}\text { New Zealand 4/ } \\
\text { Palau } \\
\text { Papua New Guinea } \\
\text { Samoa } \\
\text { Solomon Islands } \\
\text { Timor-Leste } \\
\text { Tonga } \\
\end{array}$ & $\begin{array}{l}\text { Tuvalu } \\
\text { Vanuatu }\end{array}$ \\
\hline Europe & $\begin{array}{l}\text { Albania } \\
\text { Austria } \\
\text { Belarus } \\
\text { Belgium } \\
\text { Bosnia \& Herzegovina } \\
\text { Bulgaria } \\
\text { Croatia } \\
\text { Cyprus } \\
\text { Czech Republic } \\
\text { Denmark } \\
\text { Estonia } \\
\text { Finland } \\
\text { France } \\
\text { Germany } \\
\text { Gibraltar } \\
\end{array}$ & $\begin{array}{l}\text { Greece } \\
\text { Hungary } \\
\text { Iceland } \\
\text { Ireland } \\
\text { Italy } \\
\text { Kosovo (2012) 1/ } \\
\text { Latvia } \\
\text { Liechtenstein } \\
\text { Lithuania } \\
\text { Luxembourg } \\
\text { Macedonia, FYR } \\
\text { Malta } \\
\text { Moldova (2004) 1/ } \\
\text { Montenegro (2010) } \\
\text { Netherlands } \\
\end{array}$ & $\begin{array}{l}\text { Norway } \\
\text { Poland } \\
\text { Portugal } \\
\text { Romania } \\
\text { Russian Federation } \\
\text { Serbia } \\
\text { Slovak Republic } \\
\text { Slovenia } \\
\text { Spain } \\
\text { Sweden } \\
\text { Switzerland } \\
\text { Turkey } \\
\text { Ukraine } \\
\text { United Kingdom }\end{array}$ & $\begin{array}{l}\text { Israel } \\
\text { San Marino }\end{array}$ & & \\
\hline $\begin{array}{l}\text { Middle East and } \\
\text { Central Asia }\end{array}$ & $\begin{array}{l}\text { Afghanistan (2009) } \\
\text { Algeria } \\
\text { Armenia (2005) 1/ } \\
\text { Azerbaijan (2007) 1/ } \\
\text { Bahrain } \\
\text { Jordan }\end{array}$ & $\begin{array}{l}\text { Kazakhstan } \\
\text { Kyrgyz Republic (2008) 1/ } \\
\text { Lebanon } \\
\text { Libya (2010) } \\
\text { Mauritania (2008) 1/10/ } \\
\text { Morocco }\end{array}$ & $\begin{array}{l}\text { Oman } \\
\text { Sudan } \\
\text { Tajikistan (2004) 1/ } \\
\text { Turkmenistan } \\
\text { Uzbekistan } \\
\text { Yemen (2008) 1/ }\end{array}$ & $\begin{array}{l}\text { Djibouti } \\
\text { Egypt } \\
\text { Georgia } \\
\text { Iran } \\
\text { Iraq } \\
\text { Kuwait }\end{array}$ & $\begin{array}{l}\text { Pakistan } \\
\text { Qatar } \\
\text { Saudi Arabia } \\
\text { Syrian Arab Republic } \\
\text { Tunisia } \\
\text { United Arab Emirate }\end{array}$ & \\
\hline $\begin{array}{l}\text { Western } \\
\text { Hemisphere }\end{array}$ & $\begin{array}{l}\text { Argentina } \\
\text { Bahamas, The } \\
\text { Barbados (2007) 1/ } \\
\text { Brazil } \\
\text { Canada } \\
\text { Chile } \\
\text { Colombia }\end{array}$ & $\begin{array}{l}\text { Ecuador } \\
\text { El Salvador } \\
\text { Guatemala } \\
\text { Honduras } \\
\text { Jamaica } \\
\text { Mexico } \\
\text { Nicaragua }\end{array}$ & $\begin{array}{l}\text { Paraguay } \\
\text { Peru } \\
\text { Trinidad and Tobago } \\
\text { United States } \\
\text { Uruguay } \\
\text { Venezuela }\end{array}$ & $\begin{array}{l}\text { Antigua and Barbuda } \\
\text { Belize } \\
\text { Bolivia 5/ } \\
\text { Costa Rica } \\
\text { Dominica } \\
\text { Dominican Republic 6/ } \\
\text { Grenada } \\
\end{array}$ & $\begin{array}{l}\text { Guyana } \\
\text { Haiti } \\
\text { Panama } \\
\text { St. Kitts and Nevis } \\
\text { St. Lucia } \\
\text { St. Vincent and the C } \\
\text { Suriname } \\
\end{array}$ & \\
\hline
\end{tabular}


Notes:

1/ Explicit deposit insurance scheme introduced since previous release of the deposit insurance database in 2004.

2/ Covered by the deposit insurance scheme of the United States (FDIC).

3/ Insurance product tailored to small retail depositors provided to private banks by a state-run insurance company. Several large banks, including Kanbawza and Co-operative Bank, have participated as of 2011

4/ New Zealand introduced an opt-in retail deposit guarantee scheme in October 2008 and closed it in December 2010. Deposits held in New Zealand branches of Australian branches were covered under the Australian deposit insurance scheme from 2008 - 2010, but current legislation will limit coverage to Australian dollar-denominated deposits only.

5/ Bolivia has a bank resolution fund with funding provided by member banks, but no explicit deposit insurance.

6/ The Dominican Republic has no deposit insurance for commercial banks, but there is a scheme (established in 1962) insuring the savings and term deposits in savings and loan associations. In the past, the Central Bank has guaranteed deposits at Bancomercio (1996) and Baninter (2003) when these large banks failed.

7/ In 2009, Cameroon, Central African Rep., Chad, Congo (Rep), Equatorial Guinea, and Gabon, which share a regional central bank, established the Fonds de Garantie des Depots en Afrique Centrale (FOGADAC), a regional deposit insurance scheme that became operational in 2011.

8/ The Sri Lanka Deposit Insurance Scheme (SLDIS) became effective on January 1, 2012, although member banks and finance companies participating in this scheme already started contributing on a mandatory basis starting on October 1, 2010.

9/ Taiwan (ROC) has deposit insurance but is not an IMF member.

10/ A deposit guarantee fund (Fonds de Garantie des Dépôts) exists on the basis of the deposit guarantee law of 2008 but has not become operational yet as of end-2013.

Sources: World Bank Survey, IADI, Laeven and Valencia (2012), FSB (2010, 2012), IMF staff reports, and national deposit insurance agencies. 
Table 2. Coverage of Explicit Deposit Insurance Schemes Around the World, end-2013

\begin{tabular}{|c|c|c|c|c|c|c|c|c|c|c|c|c|}
\hline \multirow{3}{*}{ Country } & \multicolumn{6}{|c|}{ Statutury limit } & \multicolumn{3}{|c|}{ Coverage including government guarantees (USS) } & \multicolumn{3}{|c|}{ Coverage limit / GDP per capita (in \%) } \\
\hline & \multicolumn{3}{|c|}{ Reported Currency } & \multicolumn{3}{|c|}{ US Dollars } & \multirow[b]{2}{*}{2003} & \multirow[b]{2}{*}{2010} & \multirow[b]{2}{*}{2013} & \multirow[b]{2}{*}{2003} & \multirow{3}{*}{$\frac{2010}{412}$} & \multirow[b]{2}{*}{2013} \\
\hline & 2003 & 2010 & 2013 & 2003 & 2010 & 2013 & & & & & & \\
\hline Afghanistan & $\begin{array}{l}\text { n.a, } \\
\text { LEK30,000; } 85 \% \text { of }\end{array}$ & AF100,000 & AF100,000 & n.a. & 2222 & 1767 & n.a. & 2222 & 1767 & n.a. & & 260 \\
\hline Albania & $\begin{array}{l}\text { next LEK } 411,765 \text { (up to maximum of } \\
\text { LEK } 700,000 \text { ) }\end{array}$ & LEK2,500,000 & LEK2,500,000 & 5796 & 24032 & 24498 & 5796 & 24032 & 24498 & 319 & 586 & 531 \\
\hline Algeria & DIN600,000 & DIN600,000 & DIN600,000 & 7752 & 8066 & 7678 & 7752 & 8066 & 7678 & 364 & 180 & 141 \\
\hline Argentina & ARG30,000 & ARG120,000 & ARG120,000 & 10345 & 30769 & 18209 & 10345 & 30769 & 18209 & 303 & 336 & 155 \\
\hline $\begin{array}{l}\text { Armenia } \\
\text { Australia }\end{array}$ & n.a. & $\begin{array}{l}\text { AMD 4,000,000 } \\
\text { AUD1000000 }\end{array}$ & $\begin{array}{l}\text { AMD D4,000,000 } \\
\text { AUD250,000 }\end{array}$ & n.a. & $\begin{array}{l}10705 \\
917431\end{array}$ & $\begin{array}{c}9877 \\
221625\end{array}$ & n.a. & $\begin{array}{c}10705 \\
\text { UNLMITED } 1\end{array}$ & 9877 & n.a. & 377 & 308 \\
\hline $\begin{array}{l}\text { Austrafia } \\
\text { Austria }\end{array}$ & $\begin{array}{lll}\text { E.ha. } & \text { EUR20,007/ }\end{array}$ & $\begin{array}{l}\text { AUD1,000,000 } \\
\text { EUR100,000 }\end{array}$ & $\begin{array}{l}\text { AUDD250,000 } \\
\text { EUR100,000 }\end{array}$ & $\begin{array}{l}\text { n.a. } \\
22727\end{array}$ & $\begin{array}{l}917341 \\
13333\end{array}$ & ${ }_{137830}^{221625}$ & $\begin{array}{c}\text { na.a. } \\
22727\end{array}$ & $\begin{array}{l}\text { UNLIMITED 1/ } \\
133333\end{array}$ & 2137835 & $\begin{array}{l}\text { n.a. } \\
73\end{array}$ & ${ }_{226}^{168}$ & ${ }_{282}^{342}$ \\
\hline Azerbaijan, Rep. of & n.a. & AZN30,000 & AZN30,000 & & $\begin{array}{l}133333 \\
37500\end{array}$ & ${ }_{38217}^{15830}$ & .2.27. & 37500 & $\begin{array}{l}1738800 \\
38217\end{array}$ & n.a. & 638 & $\begin{array}{l}882 \\
484\end{array}$ \\
\hline Bahamas, The & BAH 50,000 & BAH50,000 & BAH50,000 & $\begin{array}{l}\text { nidi. } \\
50000\end{array}$ & 50000 & 50000 & 50000 & 50000 & 50000 & 223 & 218 & $\begin{array}{l}204 \\
213\end{array}$ \\
\hline Bahrain & $\begin{array}{l}75 \% \text { of first BHDD20,000 (up to } \\
\text { maximum of BHD5.,000) }\end{array}$ & $\begin{array}{l}75 \% \text { of first BHDD20,000 (up to maximum } \\
\text { of } 3 H D 515000)\end{array}$ & 75\% of first BHD20,000 (up to maximum & 39474 & 39474 & 39894 & 39474 & 39474 & 39894 & 262 & 170 & 145 \\
\hline Bangladesh & 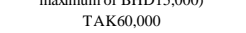 & $\begin{array}{l}\text { TAK 100,000 } \\
\text { Then }\end{array}$ & $\begin{array}{l}\text { TAK100,000 } \\
\text { Th150 }\end{array}$ & 1032 & 1425 & 1287 & 1032 & 1425 & 1287 & 271 & 203 & 142 \\
\hline Barbados & n.a. & USD12,500 & USD12,500 & n.a. & 12500 & 12500 & n.a. & 12500 & 12500 & n.a. & 78 & 81 \\
\hline Belarus & USD 1,000 & EUR5,000 & EUR5,000 & 1000 & 6667 & 6892 & 1000 & UNLIMITED 8/ & UNLIMITED & 55 & 115 & 91 \\
\hline Belgium & EUR20,000 & EUR100,000 & EUR100,000 & 22727 & 133333 & 137830 & 22727 & 133333 & 137830 & 76 & 306 & 304 \\
\hline Bossia-Herzegovina & BAM 5,000 & BАM 35,000 & BАМ 35,000 & 2890 & 23649 & 24700 & 2890 & 23649 & 24700 & 131 & 547 & 537 \\
\hline & BRR20,000 & BRR70,000 & BRR250,000 & 6536 & 39773 & 106211 & 6536 & 39773 & 106211 & 215 & 359 & 939 \\
\hline Brunei Darussalam & n.a. & BND50,000 & BND50,000 & n.a. & 36765 & 39392 & n.a. & 36765 & 39392 & n.a. & 115 & 99 \\
\hline Bulgaria & BGN15,000 & BGN196,000 & $\begin{array}{ll}B G N 196,000 \\
x \rightarrow 500000\end{array}$ & 8671 & 132432 & 137063 & 8671 & 132432 & 137063 & 328 & 2078 & 1870 \\
\hline $\begin{array}{l}\text { Cameroon } \\
\text { Canada }\end{array}$ & $\begin{array}{l}\text { n.a. } \\
\text { CaD6000 }\end{array}$ & 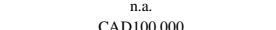 & XAF5,000,000 & $\begin{array}{c}\text { n.a. } \\
42857\end{array}$ & $\begin{array}{c}\text { n.a. } \\
9.7087\end{array}$ & ${ }^{10480}$ & $\begin{array}{c}\text { n.a. } \\
\text { 1.205 }\end{array}$ & n.a. & 10480 & n.a. & $\begin{array}{c}\text { n.a. } \\
\text { g77og. }\end{array}$ & 1031 \\
\hline $\begin{array}{l}\text { Canada } \\
\text { Central African Rep. }\end{array}$ & $\begin{array}{l}\text { CAD60,000 } \\
\text { n.a. }\end{array}$ & $\begin{array}{l}\text { CAD100,000 } \\
\text { n.a. }\end{array}$ & $\begin{array}{l}\text { CAD100,000 } \\
\text { X }\end{array}$ & 42857 & 97087 & $\begin{array}{l}{ }^{33995} \\
10480\end{array}$ & $\begin{array}{c}42857 \\
\text { na.a. }\end{array}$ & $\begin{array}{c}97087 \\
\text { n.a. }\end{array}$ & 93985 & 157 & 8799 & 7394 \\
\hline $\begin{array}{l}\text { Chad } \\
\text { Chat Arican Rep. }\end{array}$ & $\begin{array}{c}\text { n.a. } \\
\text { n.a. } \\
\text { not }\end{array}$ & $\begin{array}{c}\text { n.a. } \\
\text { n.a. }\end{array}$ & $\begin{array}{l}\text { XAF5, } 000,000 \\
\text { XAFs,00,000 }\end{array}$ & $\begin{array}{l}\text { n...e } \\
\text { n.a. }\end{array}$ & $\begin{array}{l}\text { c.a. } \\
\text { n.a. }\end{array}$ & $\begin{array}{l}10480 \\
10480\end{array}$ & $\begin{array}{l}\text { n.a. } \\
\text { n.a. }\end{array}$ & $\begin{array}{l}\text { N.a. } \\
\text { n.a. }\end{array}$ & 10480 & $\begin{array}{l}\text { N.a. } \\
\text { n.a. }\end{array}$ & $\begin{array}{l}\text { c.a. } \\
\text { n.a. }\end{array}$ & 860 \\
\hline Chile & $\begin{array}{l}90 \% \text { of first UDF120 (up to } \\
\text { maximum of UDF 108) 12/ }\end{array}$ & $\begin{array}{l}90 \% \text { of first UDF } 120 \text { (up to maximum of } \\
\text { UDF 108) } 12 /\end{array}$ & $\begin{array}{l}90 \% \text { of first UDF } 120 \text { (up to maximum of } \\
\text { UDF 108) 12/ }\end{array}$ & 2643 & 4542 & 4710 & 2643 & 4542 & 4710 & 54 & 36 & 30 \\
\hline Colombia & 75\% of first COP26,666,667 (up to & COP20,000,000 & $\mathrm{COP} 20,000,000$ & 6954 & 10584 & 10403 & 6954 & 10584 & 10403 & 306 & 168 & 128 \\
\hline Congo, Rep. & n.a. & $\begin{array}{l}\text { n.a. } \\
\text { HKN00000 }\end{array}$ & 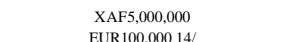 & $\begin{array}{c}\text { n.a. } \\
14925\end{array}$ & $\begin{array}{l}\text { n.a. } \\
772727\end{array}$ & $\begin{array}{l}10480 \\
137830\end{array}$ & 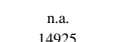 & $\begin{array}{c}\text { n.a. } \\
72727\end{array}$ & $\begin{array}{l}10480 \\
147830\end{array}$ & n.a. & $\begin{array}{l}\text { n.a. } \\
530 .\end{array}$ & 318 \\
\hline Croatia & 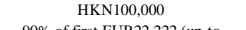 & HKN400,000 & EUR100,000 14/ & 14925 & 72727 & 137830 & 14925 & 72727 & 137830 & 194 & 530 & 1016 \\
\hline Cyprus & $\begin{array}{l}90 \% \text { of first EUR22,2222 (up to } \\
\text { maximum of EUR20,000) }\end{array}$ & EUR100,000 & EUR100,000 & 22727 & 133333 & 137830 & 22727 & 133333 & 137830 & 123 & 485 & 557 \\
\hline Czech Republic & $\begin{array}{l}90 \% \text { of first EUR27,778 (up to } \\
\text { maximum of FUR } 5000 \text { ) }\end{array}$ & EUR100,000 & EUR100,000 & 28409 & 133333 & 137830 & 28409 & 133333 & 137830 & 304 & 703 & 731 \\
\hline Denmark & DKK 300,000 & EUR100,000 & EUR100,000 & 45524 & 133333 & 137830 & 45524 & 133333 & 137830 & 115 & 236 & 233 \\
\hline Ecuador & USD7,416 & USD27,000 & USD 31,000 & 7416 & 27000 & 31000 & 7416 & 27000 & 31000 & 339 & 583 & 519 \\
\hline El Salvador & USD6,700 & USD9,000 & USD9,800 & 6700 & 9000 & 9800 & 6700 & 9000 & 9800 & 268 & 261 & 253 \\
\hline Equatorial Guinea & n.a. & n.a. & XAF5,000,000 & n.a. & n.a. & 10480 & n.a. & n.a. & 10480 & n.a. & n.a. & 51 \\
\hline Estonia & ЕКК100,000 & EUR100,000 & EUR100,000 & 7263 & 133333 & 137830 & 7263 & 133333 & 137830 & 100 & 936 & 724 \\
\hline $\begin{array}{l}\text { Finland } \\
\text { France }\end{array}$ & EUR25,000 & EUR100,000 & EUR100,000 & 28409 & 133333 & 137830 & 28409 & 133333 & 137830 & 90 & 302 & 292 \\
\hline $\begin{array}{l}\text { France } \\
\text { Gabon }\end{array}$ & $\begin{array}{l}\text { EUR70,000 } \\
\text { n.a. }\end{array}$ & EUR100,000 & $\begin{array}{ll}\text { EUR 100,000 } \\
X A 500000\end{array}$ & 79545 & 133333 & 137830 & 79545 & 133333 & 137830 & 276 & 326 & 321 \\
\hline $\begin{array}{l}\text { Gabon } \\
\text { Germany }\end{array}$ & $\begin{array}{l}\text { n.a. } \\
\text { of first EUR22.222 (up to }\end{array}$ & n.a. & XAF5,000,000 & n.a. & n.a. & 10480 & n.a. & n.a. & 10480 & n.a. & n.a. & 85 \\
\hline Germany & 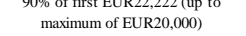 & EUR100,000 & EUR100,000 & 22727 & 133333 & 137830 & 22727 & 133333 & 137830 & 77 & 329 & 306 \\
\hline Gibraltar & EUR50,000 & EUR100,000 & EUR100,000 & 56818 & 133333 & 137830 & 56818 & 133333 & 137830 & 181 & 254 & 203 \\
\hline Greece & EUR20,000 & EUR100,000 & EUR100,000 & 22727 & 133333 & 137830 & 22727 & 133333 & 137830 & 130 & 506 & 631 \\
\hline $\begin{array}{l}\text { Guatemala } \\
\text { Hoduras }\end{array}$ & GTQ20,000 & (1) & (1) & 2519 & 2481 & 2549 & 2519 & 2481 & 2549 & 139 & 86 & 73 \\
\hline $\begin{array}{l}\text { Honduras } \\
\text { Hong Kong }\end{array}$ & $\begin{array}{l}\text { USD9,632.92 } 16 / \\
\text { n.a. }\end{array}$ & USD,6332.92 & $\begin{array}{l}\text { USDD,632.92 } \\
\text { HKD50000 }\end{array}$ & 9633 & $\begin{array}{r}9633 \\
66350\end{array}$ & 9633 & 9633 & 9633 & 9633 & 784 & 467 & 415 \\
\hline Hong Kong & $\begin{array}{l}\text { n.a. } \\
\text { nf first HUF.333.333 }\end{array}$ & HKD500000 & HKD500000 & n.a. & 64350 & 64516 & n.a. & UNLIMITED 2/ & 64516 & n.a. & 198 & 171 \\
\hline Hungary & $\begin{array}{l}\text { maximum of HUF } 3,000,000) \\
\text { mons }\end{array}$ & EUR100,000 & EUR100,000 & 13374 & 133333 & 137830 & 13374 & 133333 & 137830 & 162 & 1047 & 1028 \\
\hline Iceland & ISK2,091,000 & ISK3,425,000 & EUR20,887 & 27259 & 28019 & 28789 & 27259 & 28019 & 28789 & 72 & 71 & 63 \\
\hline $\begin{array}{l}\text { India } \\
\text { Indonesia }\end{array}$ & $\begin{array}{l}\text { INR100,000 } \\
\text { n.a. }\end{array}$ & $\begin{array}{l}\text { INR21000000 } \\
\text { IDR200000000 }\end{array}$ & $\begin{array}{l}\text { INRR1000000 } \\
\text { IDR200000000 }\end{array}$ & $\begin{array}{l}2147 \\
\text { na. }\end{array}$ & $\begin{array}{c}21722 \\
220072\end{array}$ & $\begin{array}{c}1613 \\
162999\end{array}$ & $\begin{array}{l}2147 \\
\text { UNLIMTED 3/ }\end{array}$ & $\begin{aligned} & 2172 \\
220072 & \end{aligned}$ & $\begin{array}{l}1613 \\
162999 \\
\end{array}$ & $\begin{array}{l}384 \\
\text { n.a. }\end{array}$ & $\begin{array}{l}152 \\
7373\end{array}$ & $\begin{array}{c}107 \\
4644\end{array}$ \\
\hline Ireland & $90 \%$ of first EUR22,222 (up to & EUR100,000 & EUR100,000 & 22727 & 133333 & 137830 & 22727 & 133333 & 137830 & 57 & 289 & 302 \\
\hline Italy & EUR103,291 & EUR100,000 & EUR100,000 & 117376 & 133333 & 137830 & 117376 & 133333 & 137830 & 446 & 383 & 397 \\
\hline Jamaica & JMD300,000 & JMD600,000 & JMD600,000 & 5196 & 6892 & 5661 & 5196 & 6892 & 5661 & 145 & 143 & 110 \\
\hline Japan & JPY10,000,000 & JPY10,000,000 & JPY10,0 & 86259 & 1139 & 949 & 86259 & 113921 & 94967 & 256 & 265 & 247 \\
\hline Jordan & JOD10,000 & $\begin{array}{l}\text { JOD } 10,000 \\
\text { J7TT, }\end{array}$ & JOD50,000 & 14085 & 14085 & 70641 & 14085 & UNLIMITED 10/ & 70641 & 713 & 326 & 1365 \\
\hline 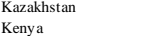 & $\begin{array}{l}\text { KZT T400,000 } \\
\text { KES100000 }\end{array}$ & $\begin{array}{l}\text { KZT5,000,000 } \\
\text { KES100000 }\end{array}$ & $\begin{array}{l}\text { KZT5,000,000 } \\
\text { KES100000 }\end{array}$ & 2676 & 33931 & $\begin{array}{l}32550 \\
1157-150\end{array}$ & 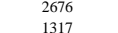 & 33931 & 32550 & 129 & 377 & 253 \\
\hline $\begin{array}{l}\text { Kenya } \\
\text { Korea, Rep. }\end{array}$ & $\begin{array}{c}\text { KESS100,000 } \\
\text { KRW50,000,000 }\end{array}$ & $\begin{array}{c}\text { KESS100,000 } \\
\text { KRW50,000,000 }\end{array}$ & $\begin{array}{c}\text { KESS100,000 } \\
\text { KRW50,000,000 }\end{array}$ & $\begin{array}{l}1317 \\
41960\end{array}$ & $\begin{array}{l}1228 \\
43250\end{array}$ & $\begin{array}{l}1157 \\
47366\end{array}$ & $\begin{array}{r}1317 \\
41960\end{array}$ & $\begin{array}{l}1258 \\
43250\end{array}$ & $\begin{array}{l}1157 \\
47366\end{array}$ & 299 & $\begin{array}{l}160 \\
211\end{array}$ & $\begin{array}{l}114 \\
195\end{array}$ \\
\hline $\begin{array}{l}\text { Korea, Kep. } \\
\text { Kosovo }\end{array}$ & $\begin{array}{l}\text { KरW } \\
\text { n.a. } \\
\text { no. }\end{array}$ & $\begin{array}{l}\text { KRW } \\
\text { n.a. }\end{array}$ & $\begin{array}{l}\text { ERWR3,0000 } \\
\text { EUR3,000 }\end{array}$ & $\begin{array}{l}\text { n.a. } \\
\text { n.a. }\end{array}$ & $\begin{array}{c}34250 \\
\text { n.a. }\end{array}$ & ${ }_{4135}^{4 / 350}$ & $\begin{array}{c}41900 \\
\text { n.a. }\end{array}$ & 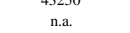 & $\begin{array}{l}41356 \\
4135\end{array}$ & n.a. & .... & 116 \\
\hline Kyrgyz Republic & n.a. & KGS100,000 & KGS100,000 & n.a. & 2175 & 2031 & n.a. & 2175 & 2031 & n.a. & 249 & 159 \\
\hline Lao PDR & KIP15,000,000 & KIP20,000,000 & KIP20,000,000 & 1426 & 2384 & 2498 & 1426 & 2384 & 2498 & 393 & 222 & 169 \\
\hline Latvia & EURA,600 & EUR100,000 & EUR 100,000 & 5227 & 133333 & 137830 & 5227 & & 137830 & 109 & 1173 & 906 \\
\hline Lebanon & LBP5,000,000 & LBP5, 000,000 & LBP5,000,000 & 3317 & 3317 & 3320 & 3317 & 3317 & 3320 & 65 & 38 & 33 \\
\hline
\end{tabular}


Table 2. Coverage of Explicit Deposit Insurance Schemes Around the World, end-2013 (continued)

\begin{tabular}{|c|c|c|c|c|c|c|c|c|c|c|c|c|}
\hline \multirow[b]{2}{*}{ Country } & \multicolumn{6}{|c|}{ Statutory limit } & \multicolumn{3}{|c|}{ Coverage including government guarantees (US\$) } & \multicolumn{3}{|c|}{ Coverage limit/ GDP per capita (in \%) } \\
\hline & \multicolumn{3}{|c|}{ Reported Currency } & \multicolumn{3}{|c|}{ US Dollars } & 2003 & 00 & 2013 & 2003 & 2010 & 2013 \\
\hline & & 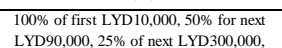 & 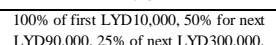 & & & & & & & & & \\
\hline Libya & n.a. & 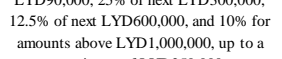 & 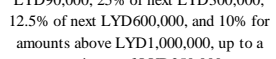 & n.a. & 197316 & 201873 & n.a. & 197316 & 201873 & n.a. & 1597 & 1828 \\
\hline Liechtenstein & EUR20000 & $\begin{array}{l}\text { maximum of LYD250,000 } \\
\text { CHF }\end{array}$ & $\begin{array}{c}\text { maximum of LYD250,000 } \\
\text { CHF } 10000,0\end{array}$ & 22727 & 96154 & 112170 & 22727 & & & & & \\
\hline Lithuania & $100 \%$ of first LTL 10,$000 ; 90 \%$ of & EUR 100,000 & EUR100,000 & 14706 & 133333 & 137830 & 14706 & 133333 & 137830 & 273 & 1125 & 861 \\
\hline Luxembourg & $\begin{array}{l}90 \% \text { of first EUR22,222 (up to } \\
\text { maximum of EUR20,000) }\end{array}$ & EUR100,000 & EUR100,000 & 22727 & 133333 & 137830 & 22727 & 133333 & 137830 & 35 & 130 & 125 \\
\hline Macedonia, FYR & $100 \%$ of first EUR 10,$000 ; 90 \%$ of & EUR30,000 & EUR30,000 & 22727 & 40000 & 41349 & 22727 & 40000 & 41349 & 969 & 879 & 836 \\
\hline Malaysia & n.a. & MYR250,000 & MYR250,000 & n.a. & 77640 & 75896 & UNLIMITED $4 /$ & 77640 & 75896 & n.a. & 897 & 720 \\
\hline Malta & $90 \%$ of first EUR22,222 (up to & EUR100,000 & EUR100,000 & 22727 & 13333 & 137830 & 22727 & 13333 & 137830 & 177 & 645 & 603 \\
\hline Marshall Islands & $\begin{array}{l}\text { maximumim or } \\
\text { USD 100,000,000) }\end{array}$ & USD250,000 & USD250,000 & 100000 & 250000 & 250000 & 100000 & $25000013 /$ & 250000 & 4107 & 8114 & 7731 \\
\hline Mexico & $10,000,000$ UDI $18 /$ & $10,000,000$ UDI $18 /$ & 400,000 UDI $18 /$ & 2984865 & 146515 & 154876 & 2984865 & 146515 & 154876 & 1988 & 1594 & 1457 \\
\hline Micronesia & USD 100,000 & USD250,000 & USD250,000 & 100000 & 250000 & 250000 & 100000 & $25000013 /$ & 250000 & 4359 & 8734 & 7776 \\
\hline $\begin{array}{l}\text { Moldova } \\
\text { Monopolia }\end{array}$ & n.a. & $\begin{array}{l}\text { MDL6000 } \\
\text { MNTT0000 }\end{array}$ & $\begin{array}{l}\text { MDL6,000 } \\
\text { MVT200000 }\end{array}$ & n.a. & ${ }^{485}$ & 460 & n.a. & 485 & 460 & n.a. & 30 & 21 \\
\hline $\begin{array}{l}\text { Mongglolia } \\
\text { Montenego }\end{array}$ & $\begin{array}{l}\text { n.a. } \\
\text { n.a. }\end{array}$ & $\begin{array}{l}\text { MNT20,000,000 } \\
\text { EUR20,000 }\end{array}$ & $\begin{array}{l}\text { MNT20,000,000 } \\
\text { EUR50000 }\end{array}$ & $\begin{array}{c}\text { n.a. } \\
\text { na. }\end{array}$ & $\begin{array}{l}14841 \\
2667 \\
2667\end{array}$ & $\begin{array}{l}12202 \\
68915\end{array}$ & $\begin{array}{c}\text { n.a. } \\
\text { na. }\end{array}$ & $\begin{array}{l}\text { UNLIM ITED 15/ } \\
26667\end{array}$ & $\begin{array}{l}12202 \\
68915\end{array}$ & n.a. & 660 & $\begin{array}{l}307 \\
981\end{array}$ \\
\hline Morocco & $\begin{array}{l}\text { n.a. } \\
\text { MAD50,000 }\end{array}$ & $\begin{array}{l}\text { ERR20,000 } \\
\text { MAD80,000 }\end{array}$ & $\begin{array}{l}\text { ERTSO,000 } \\
\text { MADBo,000 }\end{array}$ & $\begin{array}{l}\text { na. } \\
5225\end{array}$ & ${ }_{9501}^{2667}$ & $\begin{array}{l}68995 \\
9790\end{array}$ & $\begin{array}{c}\text { n.a. } \\
5225\end{array}$ & ${ }_{9501}^{2667}$ & $\begin{array}{l}68995 \\
9790\end{array}$ & $\begin{array}{l}\text { n.a. } \\
316\end{array}$ & $\begin{array}{l}401 \\
333\end{array}$ & 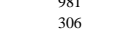 \\
\hline Nepal & n.a. & NPR200,000 & NPR200,000 & n.a. & 2683 & 2021 & n.a. & 2683 & 2021 & n.a. & $\begin{array}{l}333 \\
450\end{array}$ & 292 \\
\hline Netherlands & EUR20,000 & EUR100,000 & EUR100,000 & 22727 & 133333 & 1377830 & 22727 & 133333 & 137830 & 69 & 285 & 289 \\
\hline Nicaragua & USD 10,000 & USD 10,000 & USD10,000 & 10000 & 10000 & 10000 & 10000 & 10000 & 10000 & 994 & 690 & 544 \\
\hline $\begin{array}{l}\text { Nigeria } \\
\text { Norwaya }\end{array}$ & NGN50,000 & NGN500,000 & NGN500,000 & 387 & 3328 & 3118 & 387 & 3328 & 3118 & 76 & 224 & 184 \\
\hline & NOK2,000,000 & NOK2,000,000 & NOK2,000,000 & 282486 & 331126 & 327172 & 282486 & 331126 & 327172 & 573 & 386 & 326 \\
\hline Oman & $\begin{array}{l}75 \% \text { of first OM R26,667 (up to } \\
\text { maximum of } 20.000 \text { ) }\end{array}$ & OMR20,000 & OMR20,000 & 52632 & 52632 & 52016 & 52632 & 52632 & 52016 & 571 & 225 & 206 \\
\hline Paraguay & PYG72,930,975 $19 /$ & PYG113,061,300 19/ & PYG $124,367,40019 /$ & 25000 & 27000 & 27034 & 25000 & 27000 & 27034 & 2556 & 842 & 648 \\
\hline & PNS66,474 & & & 1967 & 30316 & 331 & 1967 & 30316 & 33151 & 863 & 582 & 497 \\
\hline Philippines & PHP100,000 & $\begin{array}{l}\text { PHP500,000 } \\
-100\end{array}$ & PHP500,000 & 1845 & 11084 & 11258 & 1845 & 11084 & 11258 & 181 & 514 & 403 \\
\hline Poland & $\begin{array}{l}100 \% \text { of first EUR1,000; } 90 \% \text { of next } \\
\text { EUR23,889 (up to maximum of }\end{array}$ & EUR 100,000 & EUR100,000 & 25568 & 133333 & 137830 & 25568 & 133333 & 137830 & 451 & 1083 & 1029 \\
\hline Portugal & $\begin{array}{l}\text { EUR22,500) } \\
\text { EUR2,500 }\end{array}$ & EUR100,000 & EUR100,000 & 28409 & 133333 & 137830 & 28409 & 133333 & 137830 & 183 & 618 & 665 \\
\hline Romania & EL & 0 & EUR10 & 3864 & 133333 & 137830 & 3864 & 133333 & 137830 & 141 & 1735 & 1547 \\
\hline Russian Federation & RUB100,000 & RUB700,000 & $\begin{array}{l}\text { RUB700,000 } \\
\text { Ren }\end{array}$ & 3257 & 23049 & 21388 & 3257 & 23049 & 21388 & 109 & 216 & 144 \\
\hline Serbia & EUR3,000 & EUR50,000 & EUR50,000 & 3409 & 66667 & 68915 & 3409 & 66667 & 68915 & 130 & 1325 & 1167 \\
\hline Singapore & n.a. & SGD20,000 & SGD50,000 & n.a. & 14706 & 39392 & n.a. & UNLIMITED 5/ & 39392 & n.a. & 32 & 72 \\
\hline Slovak Republic & $90 \%$ of first EUR22,222 (up to & EUR100,000 & EUR100,000 & 22727 & 133333 & 137830 & 22727 & UNLIMITED 9/ & 137830 & 267 & 827 & 778 \\
\hline Slovenia & $\begin{array}{l}\text { maximum of EURR20,000) } \\
\text { EUR18,500 }\end{array}$ & EUR100,000 & EUR100,000 & 21023 & 133333 & 137830 & 21023 & 133333 & 137830 & 144 & 580 & 606 \\
\hline Spain & EUR20,000 & EUR100,000 & EUR1 & 22727 & 133333 & 137830 & 22727 & 133333 & 137830 & 108 & 447 & 473 \\
\hline Sri Lanka & inci. & col & Koz 20,000 & n.a. & n.a. & 1320 & n.a. & n.a. & 1320 & n.a. & n.a. & 48 \\
\hline $\begin{array}{l}\text { Sudan } \\
\text { Sweden }\end{array}$ & $\begin{array}{l}\text { SDG1,500 } \\
\text { SKK }\end{array}$ & & SDG10,000 & 575 & 4202 & (1921 & 575 & 4202 & & 119 & 257 & 388 \\
\hline $\begin{array}{l}\text { Sweden } \\
\text { Switzerland }\end{array}$ & $\begin{array}{l}\text { SKK250,000 } \\
\text { CFF3000 }\end{array}$ & $\begin{array}{l}\text { EUR100,000 } \\
\text { CHF100,000 }\end{array}$ & $\begin{array}{l}\text { EUR1100,000 } \\
\text { CHF100000 }\end{array}$ & $\begin{array}{l}30902 \\
22222\end{array}$ & 133333 & $\begin{array}{l}137830 \\
111210\end{array}$ & $\begin{array}{l}309022 \\
22222\end{array}$ & 133333 & 137830 & 88 & 271 & 238 \\
\hline 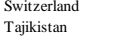 & & $\begin{array}{l}\text { CHF150,0000 } \\
\text { TIS7,000 }\end{array}$ & $\begin{array}{l}\text { CHF150,0000 } \\
\text { TIS7,000 }\end{array}$ & $\begin{array}{c}22222 \\
\text { n.a. }\end{array}$ & $\begin{array}{l}96154 \\
1598\end{array}$ & $\begin{array}{l}112170 \\
1446\end{array}$ & & $\begin{array}{l}96154 \\
1598\end{array}$ & $\begin{array}{l}112170 \\
1446\end{array}$ & $\begin{array}{l}49 \\
\text { na. }\end{array}$ & $\begin{array}{l}136 \\
216\end{array}$ & 138 \\
\hline $\begin{array}{l}\text { Talkkisanh } \\
\text { Tanzania }\end{array}$ & $\begin{array}{l}\text { Th.a. } \\
\text { TZS250,000 }\end{array}$ & $\begin{array}{l}\text { 1JS1,000 } \\
\text { TZS1,50,000 }\end{array}$ & $\begin{array}{l}\text { IJS1,0000 } \\
\text { TZS1,50,000 }\end{array}$ & $\begin{array}{l}\text { n.a. } \\
241\end{array}$ & $\begin{array}{l}1598 \\
1122\end{array}$ & $\begin{array}{l}1446 \\
944\end{array}$ & $\begin{array}{l}\text { n.a. } \\
241\end{array}$ & $\begin{array}{l}1598 \\
1122\end{array}$ & $\begin{array}{l}1146 \\
944\end{array}$ & $\begin{array}{l}\text { D.a. } \\
74\end{array}$ & $\begin{array}{l}216 \\
210\end{array}$ & $\begin{array}{l}138 \\
134\end{array}$ \\
\hline Thailand & & UNLI & THB5 & & UNLIMITED 6/ & 1523322 & UNLIMITED 6/ & UNLIMITED 6/ & 1523322 & & UNLIMITED $6 /$ & 26846 \\
\hline Trinidad \& Tobago & $\begin{array}{l}\text { ThD50,000 } \\
\text { TTD }\end{array}$ & TTPD5 & 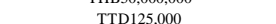 & 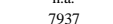 & 11774 & 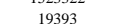 & 7937 & 11774 & $\begin{array}{l}19393 \\
19393\end{array}$ & 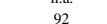 & 76 & 94 \\
\hline Turkey & TRY50,000 & TRY50,000 & TRY100,000 & 33333 & 33333 & $\begin{array}{l}453533 \\
4643\end{array}$ & 33333 & 33333 & $\begin{array}{l}36433 \\
4643\end{array}$ & $\begin{array}{l}730 \\
730\end{array}$ & 333 & $\begin{array}{l}34 \\
430\end{array}$ \\
\hline Turkmenistan & UNLIMITED & UNLIMI & UNLIM & UNLIMITED & UNLIMITED & UNLIMITED & UNLIMITED & UNLIMITED & UNLIMITED & UNLIMITED & UNLIMITED & UNLIMITED \\
\hline Uganda & UGX3,000,000 & UGX3,000,000 & UGX3,000,000 & 1593 & 1478 & 1188 & 1593 & 1478 & 1188 & 670 & 288 & 190 \\
\hline Ukraine & $\begin{array}{l}\text { UAH } 1,500 \\
\end{array}$ & UAH150,000 & UАН200,000 & 281 & 18892 & 24242 & 281 & 18892 & 24242 & 27 & 634 & 619 \\
\hline United Kingdom & $\begin{array}{l}100 \% \text { of first GBP2,000; } 90 \% \text { of next } \\
\text { GBP33,000 (up to maximum of }\end{array}$ & GBP85,000 & GBP85,000 & 51967 & 130769 & 139978 & 51967 & 130769 & 139978 & 167 & 354 & 354 \\
\hline States & GB & & & & & & & & & 262 & 518 & $471>>1$ \\
\hline $\mathrm{U}_{\mathrm{t}}$ & $\begin{array}{l}\text { USDD100,0000 } \\
\text { USD27,000 }\end{array}$ & & & 2700 & ${ }_{31612}^{25000}$ & & & & & $\begin{array}{l}262 \\
740\end{array}$ & $\begin{array}{l}178 \\
273\end{array}$ & 193 \\
\hline Uzbe & UZS1,360 & UNLIMITED 11/ & UNLIMITED $11 /$ & 1389 & UNLIMITED 1 & NLIMITED 1 & 13 & UNLIMITED 11/ & UNLIMITED 11/ & 354 & UNLIMITE & UNLIMITED 11 \\
\hline Venezuela, RB & & & & 6211 & 869 & 4774 & 6211 & 8696 & 47 & 191 & 84 & 38 \\
\hline Vietnam & VND30,000,000 & & & 1935 & $26-25>$ & 23 & 1935 & 261 & 23 & 394 & 20 & 125 \\
\hline Yen & , & & & n.a. & 9109 & 9298 & n.a. & 9109 & 9298 & n.a. & 716 & 633 \\
\hline Zimbabwe & USD3,640 & USD150 & USD500 & 3640 & 150 & 500 & 3640 & 150 & 500 & 802 & 20 & 51 \\
\hline
\end{tabular}

Notes: Coverage is all member countries with explicit deposit insurance schemes. Mauritania, Turkmenistan, and Uzbekistan are not included because of missing data. Marshall Islands and Micronesia are covered by the United States. 
1/ On October 12, 2008, Australia announced an unlimited guarantee scheme for deposits in excess of A $\$ 1$ million, the Australian Government Guarantee Scheme for Large Deposits and Wholesale Funding (the Guarantee Scheme). The Guarantee Scheme was to remain in place for a period of three years, and was voluntary and subject to a fee (for deposits exceeding A 1 million per person and bank). The Scheme formally commenced on 28 November 2008, and closed for new liabilities at the end of March 2010. Large deposits and wholesale liabilities guaranteed under the Scheme as at 31 bank). The Scheme formally commenced on 28 November 2008, and closed for new liabilities at the end of March 2010. Large deposits and wholesale liabilities guaranteed under the Scheme as at 31
March 2010 remained guaranteed, for a fee, for the relevant term. Separate deposit insurance arrangements continued to apply for deposit balances totaling up to and including A $\$ 1$ million per customer per institution, and were lowered to A \$250,000 from 1 February 2012 onwards. Such deposits are guaranteed without charge.

2/ Blanket guarantee introduced in 2008 expired at the end of 2010.

3/ Indonesia introduced explicit deposit insurance in 2004. The 2003 coverage limit refers to blanket guarantee in place.

4/ Malaysia introduced explicit deposit insurance in 2005. The 2003 coverage limit refers to blanket guarantee in place.

5/ Singapore announced on October 16, 2008 a blanket guarantee on deposits of individuals and non-bank customers of banks licensed in Singapore. The guarantee expired on December 31, 2010.

6/ An explicit guarantee system was introduced in August 2008 with the formation of the Deposit Protection Agency, replacing a blanket guarantee. The blanket guarantee is being gradually phased out with a limit of Baht 50 mln from Aug 11, 2012 - 10 Aug 10, 2015; Baht 25 million from Aug 11, 2015 - Aug 10, 2016; and Baht 1 mln for the period Aug 11,2016 - onwards.

7/ $10 \%$ coinsurance for non-private persons.

8/ State-owned banks Belarusbank and Belagroprombank benefit from a full government guarantee on all their deposits, and do not make contributions to the Guarantee Fund. By Presidential decree of November 4, 2008. Belarus subsequently extended a full guarantee on all household deposits in all banks.

9/ On October 8, 2008, the Slovak government announced a blanket guarantee on deposits, which became effective as of November 1, 2009. Blanket guarantee expired at the end of 2010.

10/ Jordanian government issued a blanket guarantee on deposits in 2008, which expired end-2010.

11/ The President of the Republic of Uzbekistan issued a decree announcing a blanket guarantee on deposits on November 28, 2008. Blanket guarantee officially in place since October 12, 2009.

Guarantee replaced statutory limit of 250 times the minimum wage. Guarantee still in place.

$12 /$ Coverage limit in Chile refers to coverage of time deposits. Demand deposits are covered in full. Maximum coverage is equivalent to a maximum of 1,827,360 pesos in 2003, 2,317,199 pesos in 2010, and 2,466,801 pesos in 2013.

13/ Full guarantee for noninterest-bearing transaction accounts until December 31, 2012.

14/ Deposit insurance coverage increased from HKN400,000 to EUR100,000 on July 1, 2013 when Croatia joined the EU.

15/ Blanket guarantee on deposits in Mongolia expired on November 2012.

16/ A blanket guarantee on deposits was in place in Honduras from 1999 until September 2003. It was reduced to 50\% coverage for October-November 2003 and increased back to 100\% for December-

September 2004, until the additioal guarantee was phased out in September 2004. Between April and September 2004 there was a guarantee ceiling of 5 million Lempiras.

17/ The equivalent of 250 times minimum wage, which equaled UZS5,440 at end-2003.

18/ Coverage limit in Mexico is equivalent to 33,520,000 pesos in 2003, 2,023,492.40 pesos in 2010, and 2,023,492.40 pesos in 2013.

19/ Equivalent of 75 times monthly minimum wage.

20/ Equivalent of 62000 FSD.

21/ Equivalent of 250,000 UI for domestic currency deposits; US\$ 2500 for foreign currency deposits.

Sources: World Bank Survey, IADI, Laeven and Valencia (2012), FSB (2010, 2012), IMF staff reports, and national deposit insurance agencies. 
Table 3. Design of Explicit Deposit Insurance Schemes Around the World, end-2013

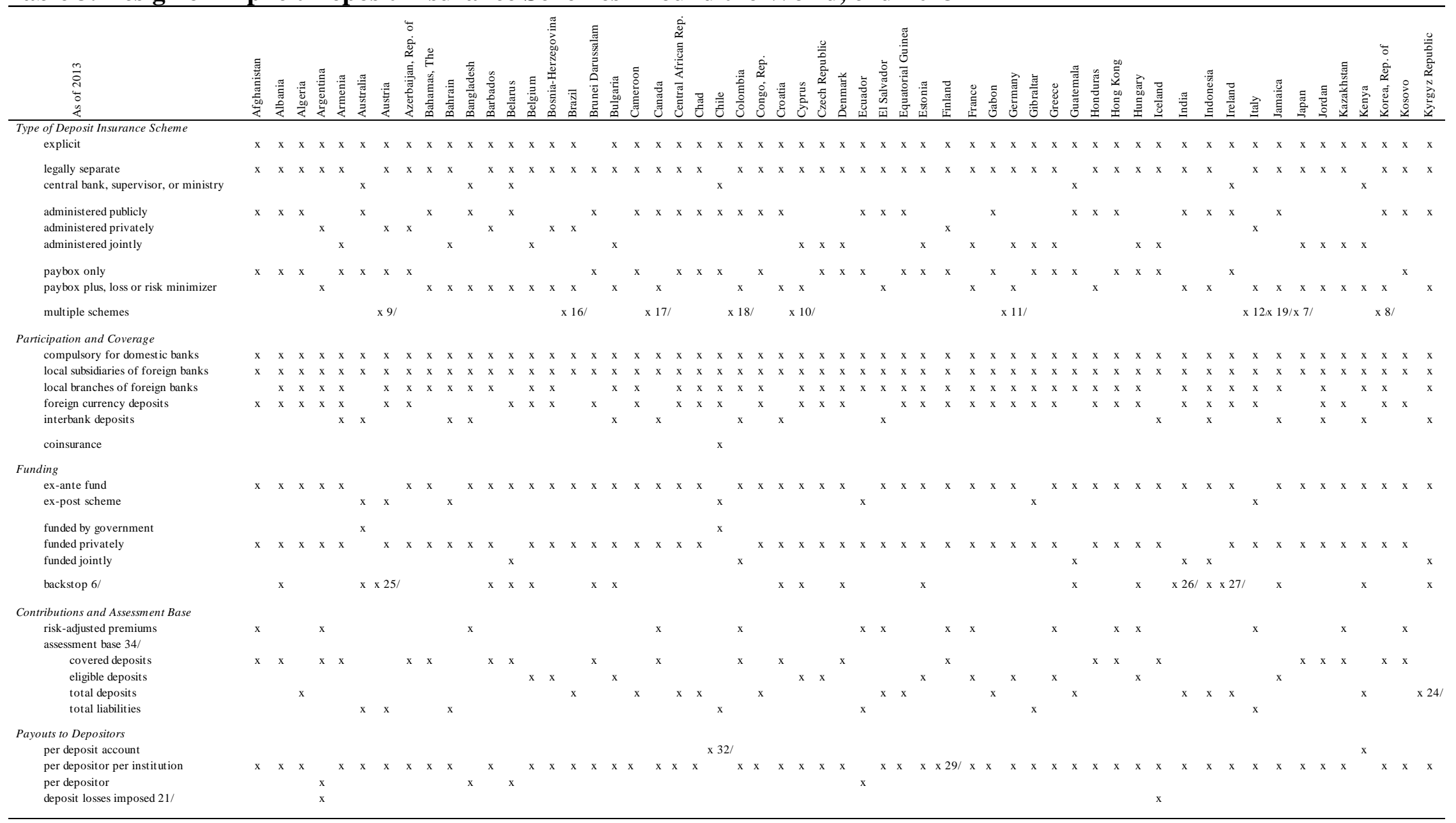


Table 3. Design of Explicit Deposit Insurance Schemes Around the World, end-2013 (continued)

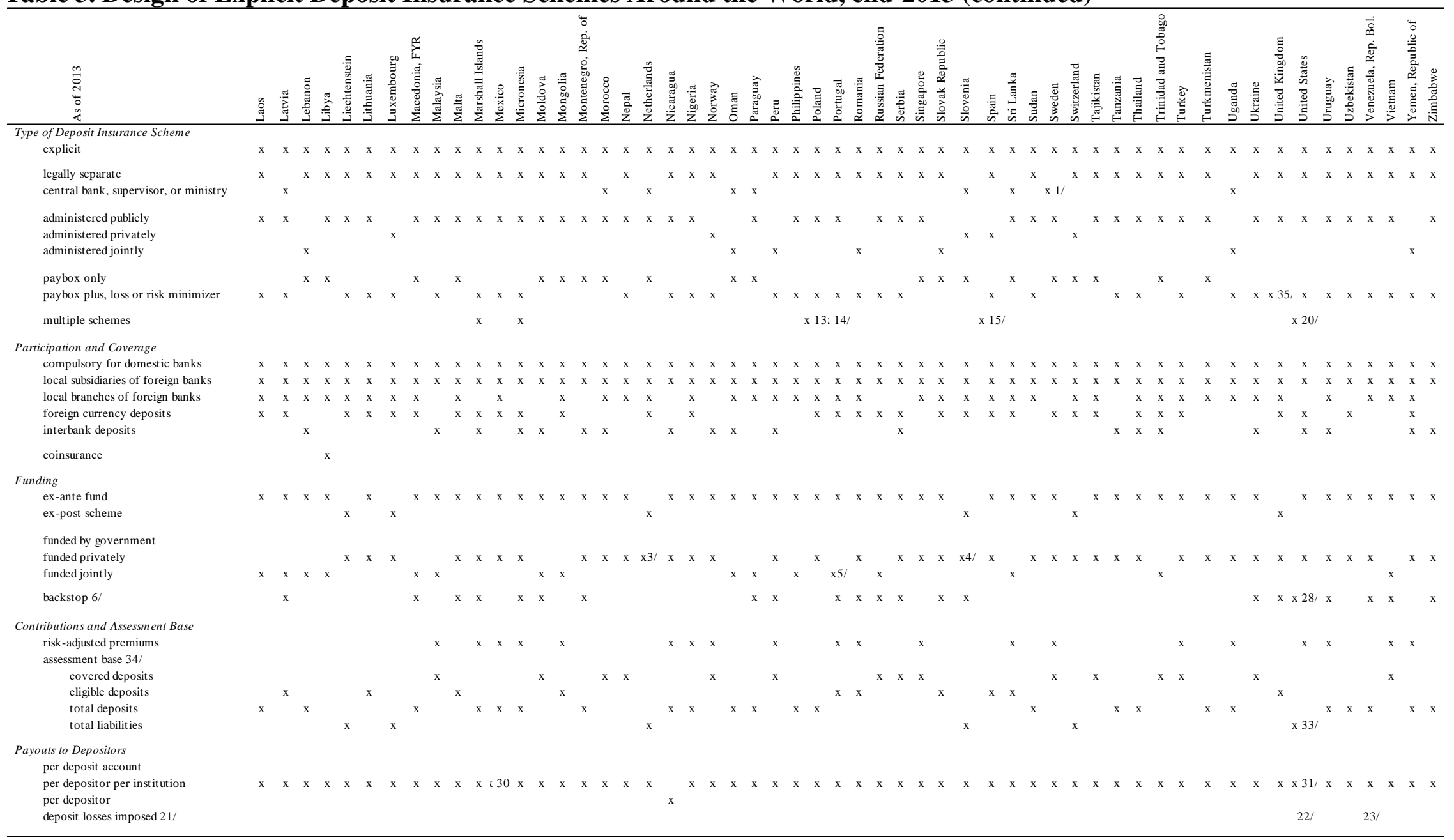

Notes: Table excludes voluntary and contractual schemes other than the national statutory scheme. Coverage is for all countries with explicit deposit insurance schemes. Information is as of 2013.

1/ Swedish National Debt Office.

2/ In 2011, the Netherlands adopted a regulation to transform its ex-post DGS into an ex-ante funded scheme with risk-based contributions, to come into effect on July 1, 2013.

3/ The Dutch Central Bank administers the scheme and pays out the depositors. The costs of the scheme are transferred (including the administrative costs) ex post to the members of the DGS, subject to an annual cap of 5\% of own funds of each member. The ex post scheme will become an ex ante scheme on July 1, 2015.

4/ In case of a bank failure, the Bank of Slovenia temporarily assumes the obligation to pay the guaranteed deposits and then calls on other banks to contribute funds needed for the paying out of insured deposits. To ensure banks have sufficient liquid assets to contribute such funds, all banks are required to invest a minimum of $2.5 \%$ of insured deposits in debt securities that are eligible for the

collateralization of Eurosystem receivables as defined by Bank of Slovenia. 
5/ Initial contribution to the DGS fund provided by Banco de Portugal.

6/ In the case of a shortfall of funds, the DGS can issue bonds/receive loans guaranteed by the government, or may access funding from the Central Bank or Ministry of Finance.

7/ Deposit Insurance Corporation of Japan and Agricultural and Fishery Cooperative Savings Insurance Corporation.

8/ Separate deposit insurance schemes exist for banks and cooperative financial institutions.

9/ Einlagensicherung der Banken \& Bankiers GmbH (Deposit Protection Company of the Austrian Commercial Banks Ltd), HYPO Haftungs GmbH, Sparkassen-Haftungs AG, Österr. RaiffeisenEinlagensicherung reg GenmbH, and Schulze-Delitzsch-Haftungsgenossenschaft regGenmbH.

10/ Deposit Protection Scheme and the Deposit Protection Scheme for Co-operative Societies.

11/ Entschädigungseinrichtung des Bundesverbandes Öffentlicher Banken Deutschlands GmbH (Compensatory fund of the Association of German Public Sector Banks), Entschädigungseinrichtung deutscher Banken GmbH (The German Private Commercial Banks Compensation Scheme for Depositors and Investors), Sicherungseinrichtung des Bundesverband der Deutschen Volksbanken und

Raiffeisenbanken (Protection Scheme of National Association of German Cooperative Banks), Haftungsverbund der Sparkassen-Finanzgruppe (Joint Liability Scheme of the Sparkassen-Finanzgruppe).

12/ Fondo Interbancario di Tutela dei Depositi (Interbank Deposit Protection Fund), Fondo di Garanzia dei Depositanti del Credito Cooperativo (Deposit Guarantee Fund of Cooperative Credit Banks).

13/ Bank Guarantee Fund and Polish Cooperative Savings and Credit Union Mutual Insurance Society.

14/ Fundo de Garantia de Depósitos (Deposit Guarantee Fund) and Fundo de Garantia do Crédito Agrícola Mútuo (Mutual Agricultural Credit Guarantee Fund).

15/ Fondo de Garantia de Depositos en Establecimientos Bancarios (Deposit Guarantee Fund For Banking Establishments), Fondo de Garantia de Depósitos en Cooperativas de Crédito (Deposit

Guarantee Funds for Credit Cooperative Banks Establishment), Fondo de Garantia de Depositos en Cajas de Ahorro (Deposit Guarantee Funds for Savings Banks Establishment).

16/ Fundo Garantidor de Crédito (FGC) cover deposits at banks, as well private deposit insurance schemes for credit unions.

17/ Canada Deposit Insurance Corporation, Autorité des Marchés Financiers, and provincial-level funds primarily for credit unions.

18/ Fondo de Guarantias de Instituciones Financieras and Fondo de Garantias de Entidades Cooperatives, for banks and cooperatives, respectively.

19/ Jamaica Deposit Insurance Corporation and Jamaica Co-operative Credit Union League.

20/ Federal Deposit Insurance Corporation, National Credit Union Share Insurance Fund, and previously the Federal Savings and Loan Insurance Corporation for commercial banks, credit unions, and savings and loans, respectively.

21/ We consider only cases of insured depositor losses where there was explicit deposit insurance. As defined, we identify only three cases. Argentina (1989): Losses were imposed on time deposits

when time deposits at BONEX were converted into long-term bonds at an exchange rate below the prevailing on the market. Argentina (2001): Dollar deposits were converted into domestic currency at ARG\$1.4, which was below the prevailing market rate. Iceland (2008): Losses imposed on depositors of foreign branches of the major Icelandic banks that failed (primarily in the Netherlands and UK), even though these deposits were explicitly covered under EU directives.

22/ In 2008, uninsured depositors of IndyMac, which entered receivership, are likely to face losses because the asset value of the receivership is insufficient to cover all uninsured deposits; so far they have received an advance dividend in the amount of $50 \%$ of their uninsured deposits from the FDIC.

23/ In 1994, depositors at Banco Latino with more than B 10m received long-term non-negotiable bonds with interest rate below market, for the amount exceeding the 10mln threshold.

24/ Total deposits without government deposits and interbank deposits.

25/ The difference to the maximum insured amount is always topped-up by the Federal Minister of Finance. Furthermore, the DIS can issued bonds with repayment guaranteed by the government. 26/ The DIS can borrow from the Reserve Bank of India.

27/ Banks are required to make up the shortfall but this is limited in any one year to the annual contribution. Any initial shortfall beyond this would be covered by the Government but would be recouped from the banks in subsequent years.

28/ The FDIC has a significant line of credit with the U.S. Treasury Department. In addition, in order to replenish the Deposit Insurance Fund, the FDIC can order special assessments on insured banks in addition to their regular assessments.

29/ The amalgamation of cooperative banks is considered to be a single institution.

30/ Deposit insurance coverage is calculated per depositor per institution and per ownership category. The ownership categories are: individual accounts, joint accounts, company/corporate accounts, trust accounts, nominee accounts.

31/ Deposit insurance coverage is based on ownership rights and capacities at any given insured depository institution. For example, a depositor may have a Single Account, which is covered up to the deposit insurance maximum and also a Joint Account, which also is covered up to the deposit insurance maximum per co-owner.

32/ Coverage of time deposits is per depositor and for demand deposits is per deposit account.

33/ Average total assets minus tangible equity (since April 1, 2011; prior to that, total domestic deposits).

34/ Total liabilities refers to the bank's total liabilities (i.e., deposits and other liabilities). Total deposits refers to the total deposits held by the bank. Eligible deposits refers to deposits repayable by the deposit insurance scheme, before the level of coverage is applied. Covered deposits refers to deposits that are covered, obtained from eligible deposits when applying the level of coverage provided for by the deposit insurance scheme.

35/ In addition to payout, the FSCS plays several roles in the special resolution regime, including informing decisions on the selection of tools, supporting the implementation of the bank insolvency procedure, and making contributions towards the cost of resolution.

Sources: European Commission, International Association for Deposit Insurers, Financial Stability Board (2010, 2012), FDIC, Laeven and Valencia (2012), IMF staff reports, and national deposit insurance agencies. 
Table 4. Recent Changes to Depositor Protection, 2007-2013

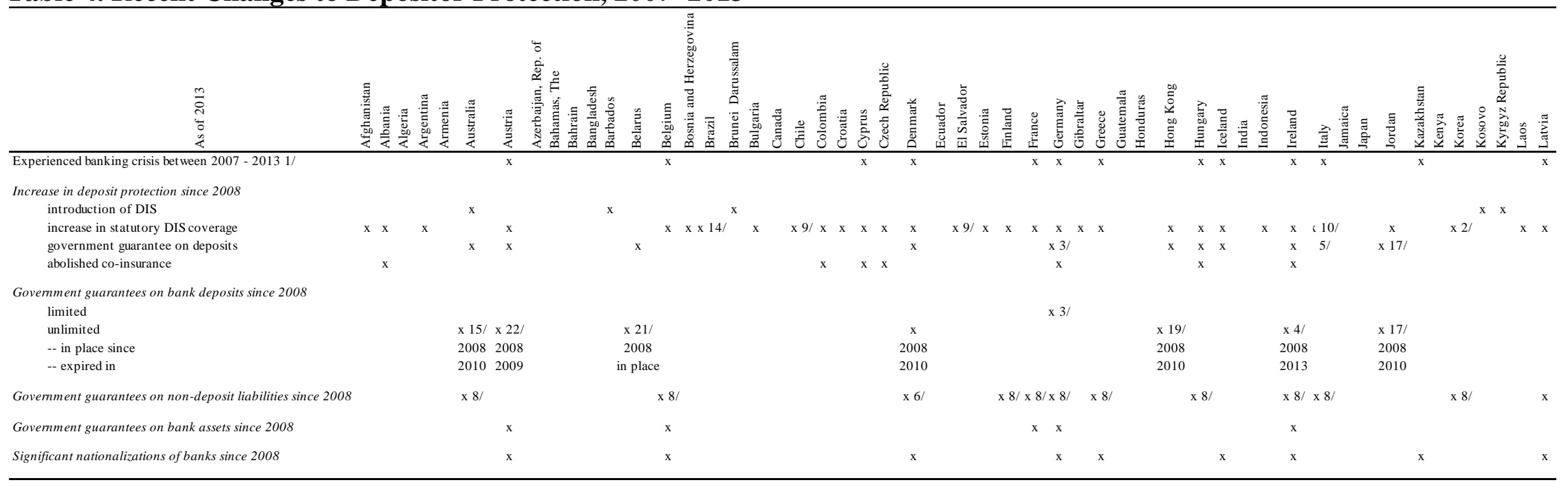


Table 4. Recent Changes to Depositor Protection, 2007-2013 (continued)

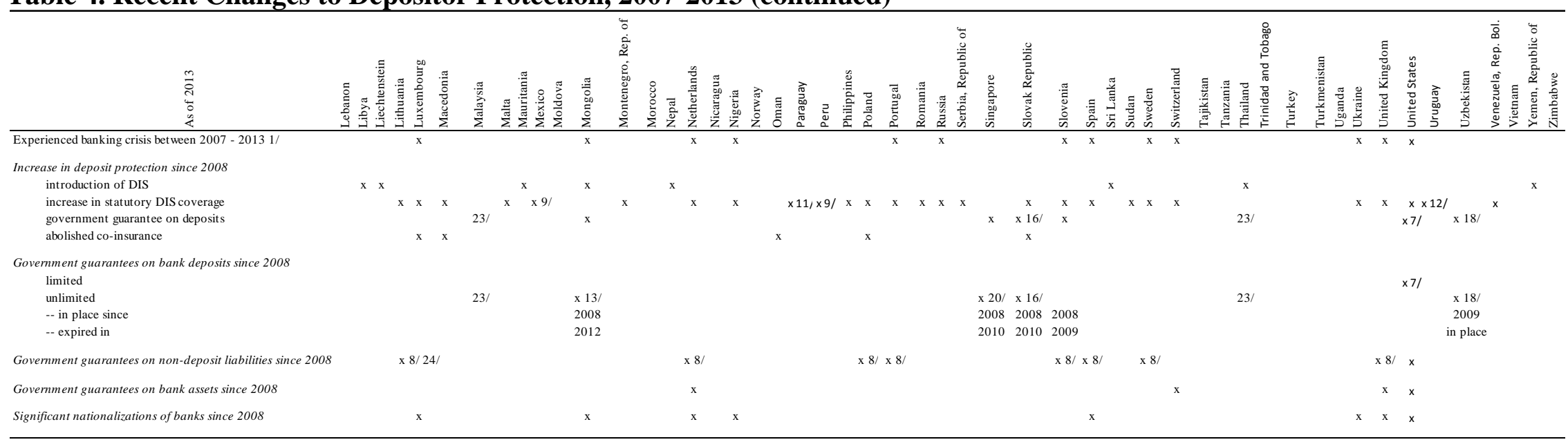

Notes: While they do not have explicit deposit insurance schemes, Kuwait, Saudi Arabia, and the United Arab Emirates extended a government guarantee on deposits during the financial crisis.

1/ Banking crisis dates for the period 2007-2011 according to Laeven and Valencia (2012). Cyprus is added to this list as of 2012.

2/ Coverage extended to include foreign currency deposits.

$3 /$ Covering only private savings accounts.

4/ On September 29, 2010, the Credit Institutions Financial Support Scheme 2008, which provided a blanket guarantee of bank liabilities and was introduced by the Minister on September 20, 2008,

expired. This blanket guarantee was succeeded by the Credit Institutions Eligible Liabilities Guarantee Scheme which was officially commenced on December 9 , 2009 and which applied to 7 major Irish credit institutions. The Eligible Liabilities Guarantee Scheme was due to expire at the end of 2012 but was extended and expired on March 28, 2013. Limited to almost all liabilities of seven major Irish financial institutions.

5/ The government guaranteed insured deposits up to the existing coverage limit in full should the insurance fund run out of funds.

6/ Excluding subordinated debt. Expired on October 10, 2010.

7/ For checking accounts only.

8/ Government guarantee of new debt issuance by banks.

9/ Indexed to inflation, so coverage increases are automatic.

10/ When Italy joined the EU, the coverage was ITL 200 million. This translated into EUR103291. Since 2010, Italy's coverage has been reduced to EUR100000, in line with the harmonized level of deposit insurance coverage as embodied in the 2009/14/EC directive.

11 / Indexed to minimum wage.

13/ On November 25, 2008, the Government of Mongolia issued a blanket deposit guarantee under the Law of Mongolia on Issuing a Guarantee for Savings held at Banks ("Deposit Guarantee Law").

This blanket guarantee had been issued amidst the financial crisis in 2008. The Deposit Guarantee Law expired on 25 November 2012 and was replaced with the introduction of an explicit deposit

insurance scheme.

14/ In addition to expanding deposit insurance coverage, the National Monetary Council allowed banks to issue a special time deposit guaranteed by the deposit insurance agency (FGC) for the issuance of securities.

15/ On October 12, 2008, Australia announced an unlimited guarantee scheme for deposits in excess of A \$1 million (the Guarantee Scheme). The Scheme formally commenced on 28 November 2008, and closed for new liabilities at the end of March 2010. Large deposits and wholesale liabilities guaranteed under the Scheme as at 31 March 2010 remained guaranteed, for a fee, for the relevant term. Separate deposit insurance arrangements continued to apply for deposit balances totaling up to and including A $\$ 1$ million per customer per institution, and were lowered to A $\$ 250,000$ from 1 February 2012 onwards. Such deposits are guaranteed without charge.

16/ On October 8, 2008, the Slovak government announced a blanket guarantee on deposits, which became effective as of November 1, 2009. Blanket guarantee expired at the end of 2010.

$17 /$ Jordanian government issued a blanket guarantee on deposits in 2008, which expired end-2010. 
18/ The President of the Republic of Uzbekistan issued a decree announcing a blanket guarantee on deposits on November 28, 2008. Blanket guarantee officially in place since October 12, 2009. Guarantee still in place.

19/ Blanket guarantee introduced in 2008 expired at the end of 2010

20/ Singapore announced on October 16, 2008 a blanket guarantee on deposits of individuals and non-bank customers of banks licensed in Singapore. The guarantee expired on December 31, 2010.

21/ State-owned banks Belarusbank and Belagroprombank benefit from a full government guarantee on all their deposits, and do not make contributions to the Guarantee Fund. By Presidential decree of November 4, 2008. Belarus subsequently extended a full guarantee on all household deposits in all banks.

22/ In October 2008, the Austrian government announced a blanket guarantee on retail deposits. The guarantee expired end-2009. In addition, as part of the Austrian Guarantee Scheme for Bank Lending announced on October 13, 2008, the Austrian government issued a limited guarantee on new bond issues by banks.

23/ Full government guarantee on deposits already in place.

24/ ForDexia only.

Sources: European Commission, Laeven and Valencia (2012), and national deposit insurance agencies. 
Table 5. Fund Size and Coverage of Existing DIS, 2010

\begin{tabular}{|c|c|c|c|c|c|c|c|c|}
\hline \multirow[b]{2}{*}{ Country } & \multicolumn{4}{|c|}{ Potential deposit liabilities, 2010} & \multicolumn{4}{|c|}{ Ability to pay, 2010} \\
\hline & Total deposits (USSbn) & Eligible deposits (USSbn) & Covered deposits (US\$bn) & Size of the DIS fund (US\$bn) & Public debt (as \% of GDP) 1/ & GDP (US\$bn) & Total deposits / GDP & Size of DIS fund / Covered deposits \\
\hline 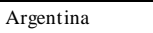 & 95 & & 27.6 & 1.21 & 49.2 & 367.6 & 25.8 & 4.4 \\
\hline Australia & 1336 & 1269.2 & 815 & 0 & 20.5 & 1247.2 & 107.1 & 0 \\
\hline Austria & 25 & & 6.5 & 0 & 72.3 & 378.4 & 6.6 & 0 \\
\hline Belgium & 704.1 & 366 & & 1.18 & 95.7 & 472.5 & 149.0 & $0.323 /$ \\
\hline Brazil & 933 & 721.2 & 205.3 & 12.73 & 65.0 & 2142.9 & 43.5 & 6.2 \\
\hline Bulgaria & 31.9 & 26.7 & 17.3 & 0.51 & 14.9 & 47.8 & 66.7 & 2.94 \\
\hline Canada & 1803 & 1153.9 & 631.1 & 2.02 & 83.1 & 1614.1 & 111.7 & 0.32 \\
\hline Cyprus & 42.4 & 76.5 & 32.6 & 0.04 & 61.3 & 23.1 & 183.5 & 0.11 \\
\hline Czech Republic & 129 & 114.4 & 65.9 & 0.54 & 37.9 & 198.5 & 65.0 & 0.82 \\
\hline Denmark & 302.5 & & 100.9 & 0.73 & 42.7 & 313.1 & 96.6 & 0.73 \\
\hline Estonia & 10.8 & 8.1 & 5 & 0.2 & 6.7 & 19.1 & 56.5 & 4.1 \\
\hline Finland & 142 & 138.3 & 60.3 & 0.81 & 48.7 & 237.1 & 59.9 & 1.34 \\
\hline France & 1742 & 1602.6 & 1167.1 & 2.45 & 82.4 & 2569.8 & 67.8 & 0.21 \\
\hline Germany & 3395 & 1358 & & 5.09 & 82.5 & 3310.6 & 102.5 & $0.372 /$ \\
\hline Greece & 371.4 & 284.4 & 177.8 & 2.33 & 148.3 & 294.8 & 126.0 & 1.31 \\
\hline Hong Kong & 877 & 859.5 & 175.4 & 0.18 & 35.5 & 228.7 & 383.5 & 0.1 \\
\hline Hungary & 88.4 & 65.3 & 34.3 & 0.38 & 82.1 & 128.0 & 69.1 & 1.11 \\
\hline India & 1166 & 1107.7 & 384.8 & 5.39 & 67.5 & 1711.0 & 68.1 & 1.4 \\
\hline Indonesia & 279 & 251.1 & 170.2 & 2.04 & 26.1 & 709.5 & 39.3 & 1.2 \\
\hline Ireland & 268.7 & & & 0.98 & 91.2 & 209.8 & 128.1 & \\
\hline Italy & 2050 & 922.5 & 635.5 & 0 & 119.3 & 2059.2 & 99.6 & 0 \\
\hline Japan & 11101 & 9990.9 & 7881.7 & 3.15 & 216.0 & 5495.4 & 202.0 & 0.04 \\
\hline Korea & 951 & 646.7 & 256.8 & 4.13 & 33.4 & 1014.9 & 93.7 & 1.61 \\
\hline Latvia & 20.3 & 16.5 & 6.5 & 0.18 & 39.7 & 24.1 & 84.2 & 2.82 \\
\hline Luxembourg & 866.3 & 130.9 & 18.3 & 0 & 19.5 & 53.0 & 1634.5 & 0 \\
\hline Malta & 58.3 & 10.7 & 8.5 & 0.01 & 66.0 & 8.4 & 694.0 & 0.13 \\
\hline Mexico & 178 & 178 & 103.2 & 0.52 & 42.2 & 1046.7 & 17.0 & 0.5 \\
\hline Netherlands & 1202 & 709.2 & 577 & 0 & 63.4 & 778.6 & 154.4 & 0 \\
\hline Portugal & 272.1 & 200.9 & & 1.99 & 94.0 & 229.4 & 118.6 & $0.992 /$ \\
\hline Romania & 93.7 & 41.6 & 26.8 & 0.33 & 31.1 & 164.8 & 56.9 & 1.23 \\
\hline Russia & 692 & 325.2 & 221.4 & 3.99 & 11.0 & 1524.9 & 45.4 & 1.8 \\
\hline Singapore & 456 & 319.2 & 86.6 & 0.11 & 98.5 & 231.7 & 196.8 & 0.13 \\
\hline Slovak Republic & 51.6 & 26.5 & 25.7 & 0.04 & 41.0 & 87.4 & 59.0 & 0.14 \\
\hline Slovenia & 30.6 & 24.4 & 12.7 & 0 & 38.7 & 47.1 & 65.0 & 0 \\
\hline Spain & 1963 & 1276 & 922.6 & 3.41 & 61.7 & 1387.4 & 141.5 & 0.37 \\
\hline Sweden & 587.7 & 336.7 & 86.3 & 2.75 & 39.4 & 463.1 & 126.9 & 3.18 \\
\hline Switzerland & 1481 & 1081.1 & 355.4 & 0 & 48.5 & 549.1 & 269.7 & 0 \\
\hline Turkey & 399 & 235.4 & 99.8 & 5.4 & 42.3 & 731.1 & 54.6 & 5.41 \\
\hline United Kingdom & 3183.2 & 1419.3 & & 0 & 78.5 & 2296.9 & 138.6 & 0 \\
\hline United States & 7888 & 7888 & 6231.5 & -7.48 & 94.8 & 14958.3 & 52.7 & -0.12 \\
\hline
\end{tabular}

Notes: Total deposits refers to total deposits held by banks in the country. Eligible deposits refers to deposits repayable by the deposit insurance scheme, before the level of coverage is applied. Covered deposits are obtained from eligible deposits when applying the level of coverage.

1/ General government gross debt (as \% of GDP). Source: IMF World Economic Outlook April 2014

2/ Size of DIS fund / Eligible deposits.

Sources: European Commission, International Association for Deposit Insurers, Financial Stability Board (2010, 2012), FDIC, Laeven and Valencia (2012), IFS, IMF staff reports, and national deposit insurance agencies. 